\title{
Composition and Variability of Downward Particulate Matter Fluxes in the Palamós Submarine Canyon (NW Mediterranean)
}

\author{
J. Martín*, A. Palanques and P. Puig \\ Institut de Ciències del Mar, CMIMA-CSIC. Departament de Geologia Marina i Oceanografia Física. \\ Passeig Marítim de la Barceloneta, 37-49,Barcelona, E- 08003, Spain.
}

\begin{abstract}
To study the temporal and spatial variability of downward particle fluxes in the Palamós Submarine Canyon, seven sediment traps were moored inside and in the vicinity of the canyon from March to November 2001. Total mass fluxes, major constituent (organic carbon, opal, calcium carbonate and lithogenics) contents and fluxes, and ${ }^{210} \mathrm{~Pb}$ activity of particulate matter were obtained from two consecutive deployments at intervals of 10 and 12 days respectively. Downward particle fluxes measured at the Palamós Canyon head were 2 to 9 times higher than those measured in other northwestern Mediterranean canyons, and this relation increases drastically at $1200 \mathrm{~m}$ depth, where observed particle fluxes are 1 to 2 orders of magnitude higher than those reported in other surrounding canyons at similar depths. The highest near-bottom downward particle fluxes were not recorded in the canyon head but in the mid-canyon axis during late spring/summer, as a result of sediment gravity flows triggered by trawling activities at the canyon rims. In comparison to the adjacent open slope, Palamós Canyon is a prime site for the focusing and across-margin transference of total and organic matter. Off-shelf sediment transport was enhanced during a severe storm in November 2001, when a sharp increase in downward particulate fluxes was observed in the whole canyon both near the bottom and at intermediate waters. Despite the dominance of lithogenic particles all year round, a siliceous bloom affected the whole study area in March-April. An asymmetrical pattern was observed between the north and south canyon walls, with higher mean downward fluxes in the latter case, a fact related to the flow regime inside the canyon. The spatial-temporal distribution of total mass fluxes and major constituents defined two domains in the Palamós Canyon: an "inner" domain (up to $1200 \mathrm{~m}$ depth) constricted by the canyon topography and mainly influenced by a lateral transport of particles resuspended from the adjoining shelf and upper slope, and an "outer" domain, where slope dynamics and seasonal trends are more important in determining the composition and amount of downward particulate fluxes.
\end{abstract}

Keywords: Particulate flux; Continental margins; Sediment trap; Submarine canyon; Western Mediterranean Sea; Palamós Canyon $\left(41-42^{\circ} \mathrm{N}, 3-4^{\circ} \mathrm{E}\right)$

* Corresponding author. Tel.: +34-932309523 ; fax: +34-932309555.

E-mail address: jmartin@icm.csic.es

Cite as: Martín, J., Palanques, A., Puig, P. 2006. Composition and Variability of Downward Particulate Matter Fluxes in the Palamós Submarine Canyon (NW Mediterranean). Journal of Marine Systems, 60(1-2): 75-97. 


\section{Introduction}

Continental margins represent one of the highest primary production zones of the ocean and receive large organic inputs from the continents. As a consequence, organic matter fluxes on the shelf and slope are generally higher than in the open ocean, which confers to margins the role of preferential sink areas for organic carbon (Etcheber et al., 1996). In fact, it has been claimed that continental margins might function as a significant sink for atmospheric $\mathrm{CO}_{2}$ (Walsh et al., 1981). The continental shelves have limited capacity to store absorbed $\mathrm{CO}_{2}$ and river-discharged carbon. If they are to be maintained as $\mathrm{CO}_{2}$ sinks, the received carbon must be buried in sediments or exported to the open sea (Liu et al., 2000). In comparison to the open continental slopes, submarine canyons represent an abrupt discontinuity that facilitates across-margin fluxes of water and particles. Some canyons act as passive depocentres for the particles leaving the shelf break (Hickey et al., 1986) but others can also convey the particulate matter deeper, acting as preferential conduits for matter transfer from the shelf to the deep basins (Gardner, 1989; Puig and Palanques, 1998; Hung et al., 2003). Inside canyons, the suspended matter can be transported through nepheloid layers (Gardner, 1989; Puig and Palanques, 1998), but turbidity currents, episodes of axis-flushing, slumping from the walls, and other gravitational processes also occur in submarine canyons (e.g. Xu et al., 2002; Puig et al., 2003) and may constitute an important process in the effective transfer of matter to the open ocean.

Numerical studies (Klinck, 1996; Ardhuin et al., 1999), laboratory simulations (Boyer et al., 2000) and in situ measurements (Durrieu de Madron, 1994; Puig et al., 2000; Petrenko, 2003) have shown that an along-slope current encountering a steep submarine canyon may undergo important modifications, causing different flow regimes on the upstream and downstream sides of the canyon. This asymmetry in water flow may also cause an asymmetry in particulate matter fluxes and composition between the two sides of the canyon system, but this point has been scarcely explored.

To advance understanding of the dynamics and composition of particulate matter inside one of the most prominent canyons of the NW Mediterranean, 6 moorings equipped with 7 sediment traps were deployed in the Palamós submarine canyon and adjacent slope within the "CANYONS" project. The locations of moorings and sediment traps 
were selected to cover the three-dimensional variability of the particulate matter fluxes in the canyon with high spatial-temporal resolution, in order to discern the different processes taking place along and across the canyon, as well as on the nearby open slope. The major objective of this paper is to evaluate the fluxes, composition and variability of downward particulate matter inside the Palamós Canyon, along the axis and on the walls, testing our results against the general trends and patterns from previous studies, and analyzing the sources and processes governing the downward fluxes inside the canyon.

\subsection{Regional background}

The Palamós Submarine Canyon, also known as La Fonera Canyon and Llafranc Canyon (Serra, 1981), has a total length of $40 \mathrm{~km}$ and a maximum depth of 2200 meters at its mouth (Figure 1). Its bifurcated head incises the continental shelf by the $90 \mathrm{~m}$ depth contour, $3 \mathrm{~km}$ from the coastline. The canyon head, roughly oriented along a north-south direction, leads to a narrow V-shaped axis oriented in a WNW-ESE direction, which gradually broadens towards the open sea. The steep canyon walls are indented by numerous tributaries (gullies). The most important river in the nearby coast is the Ter River, located $15 \mathrm{~km}$ northwest and having a mean annual water discharge (averaged over the period 1998-2004) of $10.3 \mathrm{~m}^{3} \mathrm{~s}^{-1}$.

Hydrography in the area is mainly characterized by a shelf/slope permanent density front, which separates continental waters from denser Mediterranean waters. This front approximately follows the continental shelf break of the Iberian Peninsula, and its density gradient is primarily due to salinity differences (Font et al., 1988). The general circulation is governed by a baroclinic current that follows the continental slope, in geostrophic equilibrium with the shelf/slope density front (Castellón et al., 1990). This current flows from northeast to southwest as part of the Northern Current (Fig. 1), which flows along the slope from the Gulf of Genoa to at least as far as the Gulf of Valencia (Millot, 1999). 


\section{Methods}

\subsection{Field Work and Instrumentation}

The geographical location of the mooring lines is illustrated in Figure 1. Three moorings were deployed along the canyon axis at 470, 1200 and $1700 \mathrm{~m}$ depth (M2, M3 and M5) respectively; two more below the canyon walls at $1300 \mathrm{~m}$ depth (M4 and M6); and another one on the adjacent slope (M7), $15 \mathrm{~km}$ upstream of the canyon axis, at 1300 m depth. Each mooring was equipped with one sediment trap 22 meters above the bottom (mab), except for mooring M3, which in addition to the 22 mab trap, had another one in intermediate waters (400 m depth; $800 \mathrm{mab}$ ), hereafter referred to as M3B (bottom trap) and M3I (intermediate trap). The sampling period lasted from March to November 2001 and was divided into two deployments: 20/March-06/July and 17/July-25/November respectively.

Six of the sediment traps used in this study were Technicap model PPS3/3, which has a cylindrical collecting hull with an upper aperture of $0.125 \mathrm{~m}^{2}$ and an aspect ratio $=2.5$ (1 m / $0.4 \mathrm{~m})$. A set of 12 sampling cups are attached to a rotating system that replaces the collecting cup at programmed intervals. In this study, the sampling period was set to 9 days in the first deployment and 11 days in the second deployment. The sediment trap installed on the open slope was an earlier Technicap model (PPS3), equipped with only 6 cups. Therefore, this unit was programmed with half the resolution of the rest of the traps (18 days first deployment; 22 days second deployment) to cover the same period with comparable data. The aspect ratio and collecting area were the same for both models. Following the recommendations of Knauer and Asper (1989), the moorings were designed to maintain vertical trap orientation, and properly instrumented with pressure and flow sensors at trap depths. This was accomplished by installing Aanderaa RCM9 current meters below each trap with a 10-minute sampling interval. There were no serious interruptions in the sediment trap time series during the sampling period, apart from a 10-days gap between deployments, due to maintenance and re-deployment tasks. However, some of the cups from M3I were contaminated with fishes (Notolepis sp; Domingo Lloris, pers. comm.). Analytical results from these contaminated samples showed a considerable bias and have been discarded for this paper. Two traps were overfilled with sediments due to natural causes (a severe storm), but fortunately this happened during the last sampling interval, so it did not further impair the time series. 


\subsection{Sample treatment}

Prior to deployment the cups were filled with a $5 \%(\mathrm{v} / \mathrm{v})$ formalin solution, which acts as both a poison and a preservative. This solution was prepared by mixing $37 \%$ Merck Formaldehyde and sea-water filtered through a $0.45 \mu \mathrm{m}$ filter, in a proportion of 1/7. The solution was buffered with analytical-grade sodium borate in order to avoid the dissolution of calcium carbonate. After recovery, the cups were kept at $4{ }^{\circ} \mathrm{C}$ in the dark until they were processed in the laboratory. Before the sample treatment, two kinds of filters were prepared: $47 \mathrm{~mm}$ diameter glass microfiber Whatmann GF/F filters of approximately $45 \mu \mathrm{m}$ mesh (GFF) and $47 \mathrm{~mm}, 45 \mu \mathrm{m}$ mesh nitro-cellulose white HAWP Millipore filters (NF). Before use, the GFF were rinsed with distilled water, placed for 24 hours in an oven at $550{ }^{\circ} \mathrm{C}$, and then allowed to cool for another $24 \mathrm{~h}$. Finally they were pre-weighed after $24 \mathrm{~h}$ more in a desiccation bowl. The NF filters were rinsed with distilled water and dried at $40{ }^{\circ} \mathrm{C}$ for $24 \mathrm{~h}$, and pre-weighed after $24 \mathrm{~h}$ in a desiccation bowl. Swimmers (those organisms deemed to have actively entered the trap) were removed from the samples to avoid errors in the measured fluxes. They were separated by wet-sieving the sample through a 1-mm nylon mesh, and stored in 5\% formalin solution for further analysis. Following the procedures described by Heussner et al. (1990), samples were divided into successive aliquots with the aid of a peristaltic dispenser (Jencons Ltd.), in order to get fractions of about $50 \mathrm{mg}$ (dry weight) for elemental analysis. Other fractions were also obtained and stored at $4{ }^{\circ} \mathrm{C}$ for different analysis. Subsamples for total and organic carbon were filtered onto GFF filters, while those for biogenic silica analysis were filtered onto NF filters.

\subsection{Laboratory analysis}

Total dry mass was determined gravimetrically. Several replicates were filtered onto pre-weighed Millipore cellulose acetate membrane filters, rinsed with distilled water and dried to constant weight at $40{ }^{\circ} \mathrm{C}$. Total Mass Flux, expressed as $\mathrm{mg} \mathrm{m}^{-2} \mathrm{~d}^{-1}$, was calculated as follows:

T.M.F. = Sample dry weight $(\mathrm{mg}) /\left(\right.$ collecting area $\left(\mathrm{m}^{2}\right) \cdot$ sampling interval (days)).

Total carbon was measured by high-temperature combustion and detection of the gaseous by-products in a LECO CN-2000 analyzer. Inorganic carbon was measured with a LECO CC-100 analyzer attached to the CN-2000. The CC-100 consists of a sealed chamber with a stirred bath of $\mathrm{HCl} 6 \mathrm{M}$ where the sample is placed. The gases produced are transferred to and analyzed by the $\mathrm{CN}-2000$, which calculates the 
percentage of inorganic carbon in the sample from the $\mathrm{CO}_{2}$ released. Organic carbon was then calculated as the difference between total and inorganic carbon.

Several conversion factors have been used in published studies to calculate organic matter from organic carbon: for example, 1.8 (Gordon, 1970), 2.0 (Puig and Palanques, 1998; Monaco et al., 1999; Heussner et al., 1996, 1999), 2.5 (Wollast and Chou, 2001), or 2.85 (Honda et al., 1997). Moreover, the OM/OC ratio, often assumed as a constant, may instead become an indicator of the degree of alteration of marine particles (Masuzawa et al., 2003). We have adopted a conversion factor of 2 (organic matter $=2$. organic carbon), the most commonly used in NW Mediterranean studies, in order to ensure consistency with published data.

Calcium carbonate content was calculated from inorganic carbon using the molecular mass ratio 8.33, assuming that all inorganic carbon was in the form of calcium carbonate. Biogenic silica was analyzed using a wet-alkaline extraction with sodium carbonate using the method described by Mortlock and Froelich (1989).

Finally, the lithogenic fraction was obtained as the difference between the total mass and the rest of the main components (i.e. opal + organic matter + carbonates). The term "lithogenic" can be misleading, since we suspect that contribution from detritic carbonates may occur in the sediment trap samples. However, the other widely-used term "aluminosilicates" is not a better choice, because it does not include common minerals without aluminum in their composition, like quartz $\left(\mathrm{SiO}_{2}\right)$.

${ }^{210} \mathrm{~Pb}\left(\mathrm{~T}_{1 / 2}=22.3 \mathrm{y}\right)$ activity was determined indirectly by analyzing its alpha-emitting effective daughter, ${ }^{210} \mathrm{Po}\left(\mathrm{T}_{1 / 2}=128 \mathrm{~d}\right)$, following a method modified from Nittrouer et al. (1979). ${ }^{210} \mathrm{Po}$ was chemically released from samples by leaching in $\mathrm{HCl} 6 \mathrm{~N}$ and $\mathrm{HNO}_{3}$ 15.8N. Previously, a known amount of ${ }^{209}$ Po was added to each sample as an internal tracer. After digestion, ${ }^{209} \mathrm{Po}$ and ${ }^{210} \mathrm{Po}$ were electrodeposited onto silver planchets for 24 h. ${ }^{210} \mathrm{~Pb}$ was calculated from ${ }^{210} \mathrm{Po}$ activity measured in the planchets in an EG\&G/Ortec Octete Alpha Spectrometer. The elapsed time span (2 years) between sampling and analysis allowed ${ }^{210} \mathrm{~Pb}$ to be in radioactive equilibrium with ${ }^{210} \mathrm{Po}$ in the samples.

Mean fluxes and mean concentrations were estimated as time-weighted mean fluxes and flux-weighted mean concentrations, which is equivalent to what had been collected by a single cup during the entire mooring deployment time. 


\subsection{External data}

The Ter daily river discharge was supplied by the "Agència Catalana de l'Aigua”, comprising the sum of the daily flow of the river in Girona and its main tributary, the River Onyar. Wave data was provided by the REMRO net of oceanographic buoys of "Puertos del Estado" (Ministerio de Fomento). This buoy is located at $41^{\circ} 49.8^{\prime} \mathrm{N}$, $3^{\circ} 11.2^{\prime} \mathrm{E}, 6 \mathrm{~km}$ southeast of Palamós, over the $90 \mathrm{~m}$ isobath. Since there were important interruptions in the wave height time series from the buoy, a WANA point (daily wave forecast output from the fourth generation WAve Model, WAM used by "Puertos del Estado" along the NE Spanish coast) was also used. We chose the WANA point at $41^{\circ} 52.5^{\prime} \mathrm{N}, 3^{\circ} 15.0^{\prime} \mathrm{E}$ due to its proximity to both the oceanographic buoy and the canyon.

\section{Results}

Depths and locations of sediment traps in each deployment period, along with relevant hydrodynamic data, are presented in Table 1.

Water motion around the trap (Gardner, 1980) and tilt of the mooring line (Gardner, 1985) can affect the collecting efficiency of sediment traps. Among users of PPS3 sediment traps (e.g. Carbonne, 1991; Heussner et al., 1999) it is common to adopt a 15 $\mathrm{cm} \mathrm{s}^{-1}$ limit for PPS3 trap collecting efficiency. Other authors, such as Fabres et al. (2002), cut it down to a more conservative $12 \mathrm{~cm} \mathrm{~s}^{-1}$ threshold.

Current speed values above the selected thresholds (expressed as percentages of the total data) were uncommon (Table 1$)$, the maximum value being $3.5 \%\left(>12 \mathrm{~cm} \mathrm{~s}^{-1}\right.$ criterion) at M3I, and $0.02-1.26 \%$ for near-bottom traps. The pressure transducers installed below the traps did not exhibit depth changes (resolution limit $2 \mathrm{~m}$ ) except for trap M3I, which experienced oscillations $<8 \mathrm{~m}$ during short periods (Table 1 ). We can therefore assume that the effect of tilt on trap efficiency can also be discarded.

Given the implicit limitations and uncertainties of sediment traps in quantifying downward matter fluxes, which has been and still is a matter of controversy (e.g. Thomas and Ridd, 2004, and references therein), and especially when sampling near the bottom, the results obtained from the traps and hereafter presented should be regarded as semiquantiative data. 


\subsection{Forcing conditions}

Time series of river discharge, significant wave height and wave peak period during the period of study are presented in Figure 2. Runoff from the Ter River was relatively low all the time, ranging between 2 and $8 \mathrm{~m}^{3} \mathrm{~s}^{-1}$. The most notable meteorological feature during the study period took place from November $10^{\text {th }}$ to $16^{\text {th }}$, when two consecutive severe storms struck the northwest Mediterranean, each one lasting for two days. Main wind directions were NNE-E and the peak of the storm occurred on November $11^{\text {th }}$ (Gracia et al., 2003). The oceanographic buoy located over the shelf (90 m depth) close to Palamós Canyon recorded maximum wave heights above $6 \mathrm{~m}$ and $\mathrm{Tp} \sim 9 \mathrm{~s}$ at the beginning of the storm, before ceasing to function due to the harsh weather conditions. The WANA model predicts $\mathrm{H}_{\mathrm{S}}>11 \mathrm{~m}$ at a point close to the oceanographic buoy (Figure 2c). The recurrence period for an event like this is estimated to be 20 years (Ibarra Damiá and Medina, 2003).

The mean circulation in the canyon is described in Palanques et al. (2005a). Briefly, near surface currents follow the mean direction (NE-SW) of the Northern Current; at intermediate depths, the currents are also aligned along the regional circulation, but in the inner part of the canyon (M3) the currents are more variable, suggesting a closed circulation. Near-bottom currents are more constrained to the local bathymetry, they are mainly up/downcanyon along the axis and more scattered near the canyon walls.

\subsection{Total mass fluxes (TMF)}

A general overview of time series of total particulate matter fluxes and major constituents fluxes measured by sediment traps is shown in Figure 3. Mean values of total mass fluxes and major constituents contents and fluxes for the whole study period are presented in Table 2.

Total downward mass fluxes varied by more than three orders of magnitude inside the canyon, from $40 \mathrm{mg} \mathrm{m}^{-2} \mathrm{~d}^{-1}$ below the northern wall in summer to more than $94000 \mathrm{mg}$ $\mathrm{m}^{-2} \mathrm{~d}^{-1}$ in the canyon axis at both $470 \mathrm{~m}$ (trap M2) and $1200 \mathrm{~m}$ (trap M3B) depths, during the severe storm that took place in November 2001. The maximum flux is unknown since these two traps overfilled, but we can say that the TMF yielded during the storm at $470 \mathrm{~m}$ and $1200 \mathrm{~m}$ depth were at least 94571 and $94045 \mathrm{mg} \mathrm{m}^{-2} \mathrm{~d}^{-1}$ respectively. On the open slope, mean TMF for the study period was 4 to 70 times lower than those recorded inside the canyon. 
Near-bottom TMF at the canyon head (M2) were quite steady from March to October, discounting the November overfilling (Fig. 3).

Near the bottom at $1200 \mathrm{~m}$ depth in the canyon axis (M3B), TMF displayed a wider range, from 8898 to more than $94000 \mathrm{mg} \mathrm{m}^{-2} \mathrm{~d}^{-1}$ when it overfilled in the November storm. The mean value for the study period was $44284 \mathrm{mg} \mathrm{m}^{-2} \mathrm{~d}^{-1}$, which is considerably higher than that recorded by the trap located upcanyon (M2). Maximum variability, along with important peaks as high as $91120 \mathrm{mg} \mathrm{m}^{-2} \mathrm{~d}^{-1}$, occurred during summer at M3B (Fig. 3). During the first four sampling intervals (March-April), TMF had the same variability and were slightly lower than those from M2. However, from May through August, the referred high peaks and strong variability at M3B were not mirrored in the rather steady fluxes of M2 or in any other of the deployed sediment traps. From September to early November, before the storm, TMF at M3B decreased close to spring values.

At the same $1200 \mathrm{~m}$ depth mooring, the sediment trap M3I (400 m depth) showed downward fluxes much lower (mean $10507 \mathrm{mg} \mathrm{m}^{-2} \mathrm{~d}^{-1}$ ) than those observed nearbottom. During the storm, however, total downward flux reached a distinct maximum of $65940 \mathrm{mg} \mathrm{m}^{-2} \mathrm{~d}^{-1}$, which accounted for $45.38 \%$ of the total material collected by that trap during the whole study (Table 2).

At $1700 \mathrm{~m}$ (M5), near-bottom TMF in the canyon axis did not show trends related to the upper canyon near-bottom fluxes, except for the November storm period, when a total mass maximum of $57720 \mathrm{mg} \mathrm{m}^{-2} \mathrm{~d}^{-1}$ was attained in concomitance with the overfilling of M2 and M3B. Mean total flux at M5 was $8484 \mathrm{mg} \mathrm{m}^{-2} \mathrm{~d}^{-1}$, with TMF ranging from a minimum of $870 \mathrm{mg} \mathrm{m}^{-2} \mathrm{~d}^{-1}$ to values up to 66 times higher. A marked relative maximum of $38390 \mathrm{mg} \mathrm{m}^{-2} \mathrm{~d}^{-1}$ occurred in mid-August.

Below the northern canyon wall (M4), near-bottom TMF were relatively low, with a mean downward flux of $1514 \mathrm{mg} \mathrm{m}^{-2} \mathrm{~d}^{-1}$, while variability was considerably high (see Fig. 3). A maximum of $7751 \mathrm{mg} \mathrm{m}^{-2} \mathrm{~d}^{-1}$ was obtained in the last sampling interval, coinciding with the November storm. During summer, this trap exhibited TMF as low as $41 \mathrm{mg} \mathrm{m}^{-2} \mathrm{~d}^{-1}$, the lowest found in this study.

Below the southern canyon wall (M6), mean TMF were about three times higher than those below the northern wall. At this site, although an important TMF increase took place during the storm event, the absolute maximum occurred in early spring (MarchApril), with a TMF of $12498 \mathrm{mg} \mathrm{m}^{-2} \mathrm{~d}^{-1}$. 
On the open slope (M7), the maximum downward flux occurred in spring (1069 $\mathrm{mg} \mathrm{m}^{-2}$ $\mathrm{d}^{-1}$ ). TMF decreased by up to an order of magnitude in summer. During the November storm, TMF at this slope site increased slightly, reaching $592 \mathrm{mg} \mathrm{m}^{-2} \mathrm{~d}^{-1}$.

Major constituents contents and fluxes are depicted in Figures 4-7: Lithogenics (Figure 4), carbonates (Figure 5), organic carbon (Figure 6) and biogenic silica (Figure 7).

\subsection{Lithogenics}

This fraction dominated the composition of the settling particles at all sites, and therefore lithogenic fluxes closely matched those of total mass at all sites. Contents were higher and more constant in traps M2 and M3B (Fig. 4), where lithogenic percentages were quite stable around values from 71 to $73 \%$. Maximum variability and lower percentages were recorded on the open slope, ranging from $43.77 \%$ in April to $65.85 \%$ in June-July. The rest of the traps (M3I, M4, M5, M6) exhibited an intermediate behavior, with mean values between 68 and $71 \%$ and a higher variability in spring. At all sites, lithogenic content peaked during the November storm.

\subsection{Carbonates}

At all sites, this constituent increased from spring to summer, peaked over AugustSeptember, and decreased again in October-November (Fig. 5). Inside the canyon, the time-averaged values showed a general trend of increasing carbonate content with trap depth (Table 2), from 22.95\% at $400 \mathrm{~m}$ depth (M3I) to $25.70 \%$ at $1700 \mathrm{~m}$ depth (M5). At M2 and M3B variability was lower whereas at the rest of the canyon sites the variability was higher, with minima occurring in spring. M4 showed the widest range, with $17.28 \%$ in early-April and 33.98\% in August. The rest of the near-bottom traps, despite the described temporal variability, rarely recorded values below a background level of about $22 \%$. On the open slope, carbonate contents were slightly higher than those in the canyon during most of the time, and a strong peak took place in August (33.46\%). Maximum carbonate contents were recorded between August and September at all sites, concurrently with a notable occurrence of pteropod shells in the sediment trap samples. The relative contribution of coccolithophorids to the carbonate fluxes is unknown (because only optical observations were made on the samples). Planktonic foraminifera were frequent in the samples throughout the sampling period. 


\subsection{Organic carbon and opal}

Almost all sites showed a similar temporal trend for both constituents: maximum values in spring (March-April) and lower ones from May through September, followed by a slight increase in October-November and depletion by mid-November (major storm). The only exception to these tendencies is M4, which showed some shifts from general tendencies when TMF was very low.

Values were almost always higher on the open slope for both components, with maximums in April of 20.05 and 4.29\% of opal and organic carbon content respectively (Figs. 6 and 7). Inside the canyon, temporal variability and contents of both components were lower at M2 and M3B than at the rest of the sites (Table 2).

In the M5 trap (1700 m depth) at the canyon axis, opal content gave a mean percentage of $3.61 \%$, varying from maximum values of around $10.30 \%$ in April to a minimum of $0.31 \%$ (the lowest recorded value) in mid-August, concurrent with a strong peak of TMF. In the southern wall trap and the open slope trap, maximum fluxes of both opal and carbon were attained during early spring. In a global view, however, the strikingly high TMF at M2 and especially at M3B caused their organic carbon and opal fluxes to overwhelm the fluxes of the rest of sites in a quantitative sense, no matter how wide the differences in content were. Moreover, there were also lower, albeit noteworthy, peaks of organic carbon and opal fluxes at M3I and M5 by mid-November, and a strong organic carbon flux at M5 coinciding with the local August peak of TMF.

In most traps, despite the evident seasonality, opal values never fell below a background level of about $1 \%$. This could be attributable to the method used, which loses accuracy for opal contents $<3 \%$ and also assumes a certain clay contamination error (Mortlock and Froelich, 1989). Rebound of biogenic debris could be an alternative explanation.

\section{6. ${ }^{210} \mathrm{~Pb}$ activity}

${ }^{210} \mathrm{~Pb}$ total activities and fluxes are available only for the traps deployed along the canyon axis (M2, M3B, M3I, and M5) and are shown in Figure 8. Table 3 shows mean ${ }^{210} \mathrm{~Pb}$ activities and fluxes in the sediment trap samples. Values ranged from 105.30 to 757.24 Bq kg ${ }^{-1}$. At M2, ${ }^{210} \mathrm{~Pb}$ activities showed very low fluctuations around a mean of $253.05 \mathrm{~Bq} \mathrm{~kg}{ }^{-1}$. At M3B ${ }^{210} \mathrm{~Pb}$ activity ranged from $429.67 \mathrm{~Bq} \mathrm{~kg}{ }^{-1}$ in March to 110.45 $\mathrm{Bq} \mathrm{kg}{ }^{-1}$ during the November storm, and presented a mean value of $238.13 \mathrm{~Bq} \mathrm{~kg}^{-1}$. At M3I, ${ }^{210} \mathrm{~Pb}$ mean activity was only slightly higher than in the previous traps, yielding a mean of $266.40 \mathrm{~Bq} \mathrm{~kg}$. In the deepest trap (M5), both the range and the temporal 
variability of ${ }^{210} \mathrm{~Pb}$ activities were distinctly higher than in the other 3 shallower traps (Fig. 8). ${ }^{210} \mathrm{~Pb}$ activities at M5 ranged from $141.10 \mathrm{~Bq} \mathrm{~kg}^{-1}$ at the November TMF maximum to $757.24 \mathrm{~Bq} \mathrm{~kg}^{-1}$ in the preceding sample.

The whole pool of data is graphed against TMF in Figure 9, showing an overall tendency for ${ }^{210} \mathrm{~Pb}$ activity to decrease with TMF.

\subsection{Main compositional trends}

In Figure 10, major constituents from the whole pool of samples are represented versus TMF. In Figure 11, some relationships between pairs of major constituents are tested. Carbonates contents were not clearly related to any of the other major constituents. Contents of opal and organic carbon showed a positive and significant relationship at all sites $\left(\mathrm{R}^{2}=0.77\right.$ for the whole data set).

As expected, near-bottom sediment traps showed lower values of lithogenics with distance seaward. Biogenic components were more abundant on the open slope, especially in early spring, when lithogenics attained a minimum of $46.37 \%$ of the total mass, and maximum opal and organic carbon contents of 20.05 and $4.29 \%$ respectively. The traps at $470 \mathrm{~m}$ (M2) and $1200 \mathrm{~m}$ (M3B) depth along the canyon axis showed a relatively constant composition throughout the experiment (Figs. 3-7), whereas the rest of the sites displayed higher variability, to some extent following similar temporal trends to that of the open slope. However, fluxes of constituents tended to match the trends of TMF in each trap. For this reason, despite the lower biogenic percentages at M2 and M3B, biogenic fluxes (as well as all constituent fluxes) became higher there than at the rest of the mooring sites.

In a broad view, main constituent contents showed a temporal trend closely related to the changes in TMF. The lithogenic fraction was positively related to TMF, while opal and organic carbon showed a negative relationship. Carbonates were not so clearly related to TMF and seemed to increase slightly with depth. Above certain values of TMF (around $30 \mathrm{~g} \mathrm{~m}^{-2} \mathrm{~d}^{-1}$, see Figure 10) the different constituents maintained the following approximate values: lithogenics: 72.3\%; carbonates $\sim 24 \%$; organic matter (organic carbon x 2) 1.9\%; and opal 1.8\%. These high TMF values belonged mainly to samples from M2 and M3B traps, but also to TMF peaks at M3I and M5. 


\section{Discussion}

\subsection{Sediment gravity flows in the canyon}

Results from the M3B trap violate at least two of the general trends expected from previous works and literature. The first is the general tendency for TMF to decrease with distance to the shoreline, a rather common feature in submarine canyons and continental margins in general (e.g. Puig and Palanques, 1998; Heussner et al., 1999). More particularly, Heussner et al. (1996) described this topic in three submarine canyons of the NW Mediterranean. This trend is apparently broken in the M3B trap, which shows much higher fluxes than M2 (located upcanyon) during many sampling intervals. Secondly, the seasonal variability of total fluxes is expected to show a minimum during summer in this area (Heussner et al., 1996), when the processes that propitiate enhanced fluxes (wave resuspension, river discharge, vertical mixing, current intensification) are less important. Instead, in the Palamós canyon axis at $1200 \mathrm{~m}$ we found strikingly higher fluxes from May to late-August, which were only comparable in magnitude to the November storm.

Furthermore, TMF measured at M3I was insufficient to account for the particle fluxes recorded near the bottom at the same mooring (M3B trap), so the main part of the particles that produced these TMF increases in the spring-summer period were transported laterally near the bottom.

In Figure 12, TMF of M2 have been subtracted from those of M3B. The graph shows a close agreement of fluxes during the first months of the experiment and also-to some extent-from September to the end of the experiment, which is linked to the closed circulation in the inner part of the canyon, as proposed by Palanques et al. (2005a). During the summer season, the previous situation is disrupted by a marked excess of fluxes at M3B in comparison with M2 (Fig. 12). Current meter and turbidimeter data (Palanques et al., 2005b) proved that these anomalous fluxes were associated with short-lived episodes of high turbidity and high current speed that were identifiable as sediment gravity flows. These episodes were not detected at any of the other mooring sites. Furthermore, current direction indicated that most of these gravity flows were not flowing along the canyon axis but coming from the northern wall, probably channeled from the shelf and upper slope through the gullies that incise the canyon walls. The hydrographic and meteorological data available proved to be useless for unveiling the triggering mechanisms of these sediment flows. On the other hand, turbidimeter data 
and data from log books provided by the local trawling fishery matched closely, suggesting an anthropogenic triggering mechanism (fishing gears) for these gravity flows.

During this period of sediment gravity flows, main constituents did not change greatly at this $1200 \mathrm{~m}$ site. There was just a slight increase in lithogenic content and ${ }^{210} \mathrm{~Pb}$ activity coherent with the increase in TMF. This constancy suggests a common source for the particles reaching this trap (being mainly resuspended material transported laterally), no matter whether they arrive as a consequence of human-induced or natural processes. Figures 3-7 show how deeply those high turbidity events impacted total mass and component fluxes at M3B.

Local, short-lived episodes of high turbidity and current speed also took place at $1700 \mathrm{~m}$ depth. The two strongest events occurred almost simultaneously (7 days apart) and were reflected in the sharp increase of TMF recorded in August by the M5 trap (Fig. 3). The sediment collected during this relative maximum had the lowest opal content found in the whole set of sediment trap samples of this study. This near-absence of opal is indicative of reworked sediments, since the relatively high $\mathrm{pH}$ and temperature of the Mediterranean deep water promotes an intense dissolution of the particulate opal that reaches the sea floor (Emelyanov and Shimkus, 1986; Cros, 1995), and bottom sediments are thus very poor in this constituent (Masqué et al., 2003). This opal marked minimum was also accompanied by low values of organic carbon and ${ }^{210} \mathrm{~Pb}$, suggesting resuspension of old sediments. This event was not detected in any of the other sediment traps. Whether or not the triggering mechanism for the gravity flows at M5 was fishing activities, as at M3B, remains unknown. In any case, the apparent isolation of these noteworthy events at M5 expresses the deep and local nature of some major transport processes taking place in the Palamós Canyon.

\subsection{Effects of a major storm over downward particulate fluxes}

Turning back our attention to Figure 12, the resemblance of the M2 and M3B fluxes is apparent again during fall, and definitely during the November storm, when both traps overfilled. Just prior to the storm, there was a notorious negative balance in Fig. 12 (that is, much higher fluxes at M2). We attribute this to the fact that the storm had begun at the time of the last scheduled rotation of the trap carousel. Thus, the penultimate cup of the shallower M2 trap could have collected the first increase in particle fluxes generated 
by the storm, whereas when it affected the M3B trap it had already turned to the last sampling cup.

During the storm, the increment in particle fluxes took place in the entire canyon, with especial strength along the canyon axis, and not only near the bottom but also at intermediate depths (Fig. 3). However, at the open slope site (M7), the recorded TMF values were lower during this storm than during spring, so the material transferred from the shelf to the slope during the storm was preferentially channeled through the Palamós Canyon.

Low biogenic contents were recorded in almost all traps inside the canyon during the storm, due to strong dilution by terrigenous and resuspended material that caused the trap samples to tend towards the bulk composition of the bottom sediments transported into the canyon.

\subsection{General trends of total mass fluxes}

Enhanced particle fluxes inside submarine canyons relative to adjacent open slopes have been previously reported in continental margins world-wide (e.g. Puig and Palanques, 1998; Monaco et al., 1999; Hung et al., 2003). This difference is very noteworthy in Palamós Canyon, where channeling and focusing effects are not restricted to storm periods. During the whole 8-month experiment, the fluxes were several tens of times higher in the canyon axis than on the open slope at similar depths. In addition, in storm periods the role of the canyon as a preferential path for across-slope matter transfer was further heightened. Compared with other studied northwestern submarine canyons, the Palamós Canyon seems to be more active. Downward particle fluxes measured at the canyon head were 2 to 9 times higher than those measured in the other canyons such as Lacaze-Duthiers, Planier, and Foix (Monaco et al., 1990a; Heussner et al., 1996; Puig and Palanques, 1998; Monaco et al., 1999), but this relation increased drastically at $1200 \mathrm{~m}$ depth, where near-bottom particle fluxes show peaks that are one to two orders of magnitude higher than in the other canyons at similar depths. Even if the presumed effect of sediment gravity flows and the storm at M3B are discounted, mean total flux (our tentative estimate is around $21000 \mathrm{mg} \mathrm{m}^{-2} \mathrm{~d}^{-1}$ ) are still far higher than in the other canyons. These high TMF at Palamós Canyon may be mainly related to its morphological characteristics. This submarine canyon indents the continental shelf deeply, with its head cutting the shelf up to the $90 \mathrm{~m}$ isobath, $3 \mathrm{~km}$ away from the coastline. This may propitiate focusing and direct transfer of particulate matter from the 
bottom nepheloid layer, not only through the canyon head but also through and from the steep canyon walls incised across the shelf and upper slope. This transference of particles into the canyon may be enhanced and channeled by the numerous gullies that indent the canyon walls. Furthermore, the particulate matter collected in traps M2 and M3B (and to some extent M3I, see Table 2), was fairly homogenous and similar in composition between them through time, suggesting a common origin of the particles, probably the shelf and upper-slope.

In many continental margins, particles produced or introduced in the shelf only reach the deep environment after experiencing successive deposition/resuspension periods. After several of these cycles the greater amount of organic matter is mineralized, and thereby the organic input to the deep ecosystems is limited. This scenario of limited shelf-slope organic matter export has been described for the Mid-Atlantic Bight (Biscaye et al., 1994) and other continental margins of the world (de Haas et al., 2002), and also for the Cap Ferret Canyon (Heussner et al., 1999). This pattern of sluggish transport of organic matter to the deep ocean may be by-passed in the presence of a submarine canyon as deeply incised in the shelf as Palamós Canyon, allowing for a more direct and rapid transport of organic and total particulate matter to the lower slope and deep sea, especially during storms. The NW Mediterranean has a great biodiversity and faunal abundance at great depths, which has previously been related to the influence of submarine canyons (Cartes, 1998; Gili et al., 2000). Being an oligotrophic system overall, the Mediterranean Sea must have mechanisms for the efficient recycling of energy at different scales (Margalef, 1997), and rapid across-margin transport of labile organic matter could be one of those mechanisms.

\section{4. ${ }^{210} \mathrm{~Pb}$ activity on settling particles}

On the continental shelf, the supply of ${ }^{210} \mathrm{~Pb}$ is dominated by the steady-state input from the atmosphere, which is removed by particle scavenging and sedimentation. This radionuclide can therefore be used to quantify particle fluxes and especially exports from the shelf to the open ocean (Bacon et al., 1994). Besides, it has been claimed that ${ }^{210} \mathrm{~Pb}$ activity in marine particles can be related to some of the major particulate constituents in open ocean waters (Legeleux et al., 1996; Moore and Dymont, 1998). In contrast, ${ }^{210} \mathrm{~Pb}$ activities and the major constituents of the flux measured in trap experiments on continental margins usually have poor correlations (Biscaye and 
Anderson, 1994; Radakovitch and Heussner, 1999; Radakovitch et al., 2003). In the present study, these correlations were also quite poor for each trap and considering all data together (Table 4), with the exception of the lithogenic fraction, which showed a negative relationship derived from its close affinity to TMF (which is in turn negatively related to $\left.{ }^{210} \mathrm{~Pb}\right)$.

In the light of the published studies, it seems that the processes and sources leading to scavenging of ${ }^{210} \mathrm{~Pb}$ by particles are more important than particulate composition itself in determining the ${ }^{210} \mathrm{~Pb}$ activity of particulate matter. This may be attributable to lateral transport of particles with a lower ${ }^{210} \mathrm{~Pb}$ content derived from shallower areas (transported from far away or resuspended old sediments, in which ${ }^{210} \mathrm{~Pb}$ has already suffered a substantial decay). Particles with a higher residence time in the water column, or aggregates falling all the way from the photic layer to the sea floor (and scavenging suspended matter in their path), are more likely to accumulate radionuclides. Therefore, we have used here ${ }^{210} \mathrm{~Pb}$ activity of particles as an indicator of the relative importance of vertical settling versus lateral advection processes, considering that, when lateral advection of resuspended sediments is important, ${ }^{210} \mathrm{~Pb}$ activities will decrease towards the ${ }^{210} \mathrm{~Pb}$ activity of the surficial sediments in the areas acting as particle sources.

Despite the different radionuclide ranges among sediment traps (Figure 8), when all data are considered together (Figure 9), there is a threshold TMF value of approximately $30 \mathrm{~g} \mathrm{~m}^{-2} \mathrm{~d}^{-1}$, above which the scatter of ${ }^{210} \mathrm{~Pb}$ activities decreases regardless of the trap considered, tending to an asymptotic value of around $220 \mathrm{~Bq} \mathrm{~kg}^{-1}$ (Figure 9). This suggests a common source of particles for all the 4 considered traps (canyon axis) during high downward flux events. During these events, ${ }^{210} \mathrm{~Pb}$ activities were between 100 and $200 \mathrm{~Bq} \mathrm{~kg}{ }^{-1}$. Masqué (1999) reported ${ }^{210} \mathrm{~Pb}$ activities in the range $64-108 \mathrm{~Bq}$ $\mathrm{kg}^{-1}$ in shelf sediments near the Foix Canyon (located southwards of Palamós Canyon, along the same continental margin).

In a general view (see Fig. 8), two patterns are clearly visible: traps M2, M3B and M3I show relatively narrow ranges and low values of ${ }^{210} \mathrm{~Pb}$ activities, while the opposite is true for M5, the deepest sediment trap and the farthest offshore. Looking at the ${ }^{210} \mathrm{~Pb}$ time series of M5 in detail, it can be seen that this trap represents an intermediate situation between a "near shelf break" case (e.g. M2, M3B, and M3I) and what would be expected for an "oceanic" case, i.e. higher levels all the time. Instead, at M5 the time evolution of ${ }^{210} \mathrm{~Pb}$ activities is very variable and closely related to TMF, exhibiting two opposite regimes, one of low TMF and high ${ }^{210} \mathrm{~Pb}$ activity, suggesting a predominance 
of vertical transport, and one of high TMF and low ${ }^{210} \mathrm{~Pb}$ activity, suggesting an input of laterally advected/resuspended material.

It is also noteworthy that ${ }^{210} \mathrm{~Pb}$ activities in the M3B and M3I traps were quite similar throughout the experiment, despite the fact that TMF were much higher in the former. This further supports the existence of a closed circulation in this (inner) part of the canyon (Palanques et al., 2005a). Most particles are derived from a common source (most probably the shelf and upper slope upstream of the canyon) and can be recirculated inside the canyon.

Carbonates showed the poorest correlation with the radionuclide. When considering all data together, or trap by trap, the correlation coefficients of ${ }^{210} \mathrm{~Pb}$ with both opal and organic carbon are rather poor (Table 4). However, if the data are divided into consecutive periods of time (Table 5), the correlation coefficients reveal a strong correlation between ${ }^{210} \mathrm{~Pb}$ and both opal and organic carbon $\left(\mathrm{R}^{2}=0.81\right.$ and 0.71 respectively) during early spring, and a weaker to inexistent one from then on (Table 5). We attribute this to the effective scavenging caused by settling particles arising from primary production, enriched in organic carbon and biogenic silica, which is probably indicative of a diatomaceous bloom.

\subsection{Composition of settling particles}

The dominance of lithogenics in the sediment trap samples suggests a dominant resuspended origin of the particles transported into the canyon. This was especially true for the sites at $470 \mathrm{~m}$ (M2) and $1200 \mathrm{~m}$ (M3B) depth in the canyon axis. Nevertheless, the biological signal was recognizable in almost all traps and in some cases contributed for a significant part of the downward particle fluxes.

In general, organic carbon and opal contents decreased with increasing TMF, indicating dilution of primary production inputs by terrigenous and/or resuspended material inside the canyon. This dilution was more apparent near the bottom at M2 and M3B, probably because these sites were closer to the shelf break and therefore were more exposed to lateral advection of material resuspended from the shelf.

The slope site (M7) was mainly characterized by a qualitative, seasonal variability, related to the seasonal cycle of biological production in the euphotic zone, whereas the inner part of the canyon showed an essentially quantitative variability. These two patterns complement what has been discussed above for the ${ }^{210} \mathrm{~Pb}$ activity of particles, and supports the hypothesis presented in Palanques et al. (2005a), that is, the existence 
of two distinct domains in the canyon: an "inner" canyon domain up to about $1200 \mathrm{~m}$ depth in the canyon axis that corresponds to the zone where the canyon incises the continental shelf, and an outer canyon domain downcanyon from about $1200 \mathrm{~m}$ depth. The inner domain displays a closed circulation under the influence of a higher sediment load, whereas the outer domain incises the continental slope, the circulation is more related to the mean flow, and the sediment load is lower.

The main difference between the two domains lies in the relative importance of lateral transport. Where this transport is lower, variability of TMF tends to match the seasonal primary production cycle. Taking M2 and M3B as true representatives of the inner domain, and M7 (open slope) as the extreme of outer domain characteristics, the rest of the traps show an intermediate behavior between the two extremes, i.e. between the dominance of resuspended particles, depleted in biogenic contents, and a seasonal pattern mainly governed by the seasonal pulses of primary production.

At all sites, the higher contents of opal and organic carbon in March-April were coherent with the spring biological bloom (Figs. 6 and 7), as observed previously in the northwest Mediterranean over the same period (e.g. Monaco et al., 1990b; Miquel et al., 1994; Puig and Palanques, 1998). Large organic carbon flux is more likely to be associated with a biogenic-SiO 2 bloom than with a calcium-carbonate bloom (Honjo, 1996).

All traps reached the maximum values of carbonate content between August and September, which can be partly explained by the low total mass collected during these months in almost all traps (i.e. the lesser dilution by terrigenous resuspended particles). It is noteworthy however, that these maximums were accompanied by abundant pteropod shells. Incidence of pteropods in sediment traps is fairly common in the Mediterranean and other seas. In a $200 \mathrm{~m}$ depth trap in the open Ligurian Sea, Miquel et al. (1994) found that an important part of the TMF was composed of pteropods. Also, Honjo et al. (1982) reported an 8-12\% contribution of pteropod shells to the total flux of carbonates at depth in several open ocean sites of the Atlantic and Pacific Oceans. The apparent blooms of pteropods in our study were observed from mid-August through September, in the entire canyon and the slope except at the southern wall site (M6).

Having stated that a relative maximum of biogenic carbonate occurred in summer in the whole study area, we are forced to discuss the reliability of the absolute values of contents and fluxes for this constituent, if we are to call it "biogenic". Despite the described seasonality in carbonates, values rarely fell below $20 \%$ of the total mass, and 
ranges were relatively narrow even considering the relative maxima in summer (Fig. 5). This, along with the absolute lack of correlation with any other component, TMF or ${ }^{210} \mathrm{~Pb}$ (Tables 4 and 5), suggest that a substantial part of the carbonates measured were not the result of vertical settling after production, as is presumed for most of the opal. Instead, two additional sources are proposed:

1) Riverine input of carbonate particles could be taking place. SEM examination of particulate matter in continental margins has revealed before (e.g. Katayama and Watanabe, 2003) the occurrence of detritic carbonate particles together with carbonated shells from marine organisms. Carbonates derived from rock weathering are common in the Adriatic Sea (Ravaioli et al., 2003). It is sometimes assumed that all the carbonated particles collected by a sediment trap are of biogenic origin. This view was probably inherited from the pioneering studies on sediment traps, which were mainly devoted to measuring fluxes in the open ocean, where lithogenic particles are certainly scarce and mostly due to atmospheric deposition (Chester, 1990). This situation may not be true in coastal and continental margin settings, near the influence of river runoff and resuspension of previously settled riverine particles, especially if the river drains onto a carbonated basin (as is the case of the Ter River). To our knowledge, there is no analytical method for differentiating biogenic from detritic particulate carbonates.

2) A significant amount of the carbonates produced biologically may be preserved in the sea bed long after their production, and eventually resuspended. Cros (1995) examined under SEM surficial sediments of the NW Mediterranean and observed high densities of coccoliths and other remains of carbonated shells. She noticed the rapid dissolution of siliceous shells, in contrast to the apparent accumulation of better-preserved calcareous shells. Therefore, the carbonate concentrations observed in the traps are the sum of shells recently produced in the photic layer plus a background of older biogenic carbonate, accumulated on the sea floor and transported laterally into the traps after resuspension.

\subsection{Across canyon variability of fluxes}

From the results yielded by the M4 (northern wall) and M6 (southern wall) traps, deployed at similar depths, two situations were observed. During the major storm in November, total downward fluxes were similar on both sides of the canyon. Instead, during the rest of the studied period, there was a clear asymmetry between the northern and southern canyon walls at similar (1300 m) depths. TMF were notably higher on the 
southern than on the northern wall site, while current speed showed the opposite situation (Palanques et al., 2005a). As previously discussed, the southern wall was the most representative site of the "outer domain" inside the canyon, in terms of the temporal variability of fluxes. The maximum TMF were registered during the spring biological bloom instead of the major storm, as is the case of M7. However, fluxes are much higher on the southern wall (M6) than on the slope (Fig. 3, Table 2), indicating that slope dynamics alone can not justify these results, and thus evidencing the influence of the canyon.

Through a modeling study, Klinck (1996) predicted that along-slope currents which encounter a submarine canyon at their right (as is the case of Northwestern Mediterranean canyons) will experience an onshore deflection on the upstream side and an offshore deflection on the downstream side of the canyon. This basic pattern has been observed in Palamós Canyon by hydrographic and satellite data (Masó et al., 1990). Alvarez et al. (1996) calculated the flow of the geostrophic jet on the upstream and downstream sides of Palamós Canyon, resulting in a flow almost 3 times stronger on the upstream than on the downstream side. Thus, the slope current apparently exits the canyon with some deceleration in comparison with the entrance flow, and this may allow particles to settle out of the water column on the downstream side. Moreover, it is possible that as the current is deflected upcanyon from the upstream side, it encounters a higher load of particulate matter in the "inner region" of the canyon, so when it turns offshore along the south wall, the current transports a higher load of particulate matter than when it entered the canyon on the upstream side. This would explain the asymmetries observed between the TMF recorded near the northern and southern canyon walls. The possibility of local upwelling on the south canyon wall has also been suggested (Palanques et al., 2005a).

\section{Conclusions}

Downward particle fluxes measured at the Palamós Canyon head were 2 to 9 times higher than those measured in other northwestern Mediterranean canyons, and this relation increases drastically at $1200 \mathrm{~m}$ depth, where near-bottom particle fluxes are 1 to 2 orders of magnitude higher than those observed in other surrounding canyons at similar depths. After discounting the presumed contribution of sediment gravity flows 
and a major storm, TMF at $1200 \mathrm{~m}$ are still an order of magnitude higher than in the other NW Mediterranean canyons studied.

The downward fluxes of total and organic matter inside the canyon are much greater than those found on the open slope, indicating the importance of this canyon in the focusing and across-margin transference of total and organic matter.

The whole canyon system acts as an efficient channel for off-shelf transport of total and organic particulate matter during severe storms like the one recorded in November 2001. During that storm, the canyon axis and walls were affected by a sharp increase in downward particulate fluxes, indicating a general off-shelf sediment transport channeling in the canyon. This channeling effect is further stressed when compared to the fluxes recorded by a trap at similar depths on the adjacent slope, which was weakly affected by the storm in terms of total mass fluxes.

The high sediment transport activity of the Palamós Canyon may be explained by the proximity of the canyon head to the coast and the fact that the canyon incises a wide sector of the continental shelf. All this may favor a direct transfer of particulate matter from the shelf, not only through the canyon head but also through and from the steep canyon walls incised across the shelf and upper slope. This transference of particles into the canyon may be enhanced and channeled by the numerous gullies that indent the canyon walls.

Superimposed on the above processes, very high mass fluxes were detected during summer at $1200 \mathrm{~m}$ depth, and they were identified as sediment gravity flows triggered by trawling activities at the canyon rims.

The spatial-temporal distribution of total mass fluxes and major constituents allowed two domains to be defined in the Palamós Canyon: an "inner" domain (up to $1200 \mathrm{~m}$ depth) constricted by the canyon topography and mainly influenced by a continuous, lateral transport of particulate matter from the adjoining shelf, and an "outer" domain, where slope dynamics and seasonal trends are more important in determining the composition and amount of downward fluxes.

Compositional and radiochemical analysis led us to identify a clear imprint (in MarchApril) of a siliceous bloom affecting the whole study area. Organic carbon and opal were closely associated in the particles, suggesting a rapid transport of particulate organic matter to the deep sea floor in the form of siliceous-organic aggregates, pellets and other fast-sinking particles. 
This high resolution experiment conducted in the Palamós Canyon yielded a high variability in total mass fluxes. Important events like major storms can be detected in the whole canyon in concomitance, and there are other local and ephemeral processes that are also of major importance in the total transfer of particulate matter.

\section{Acknowledgements}

This work was carried out in the framework of the CANYONS project, funded by the “Dirección General de Enseñanza Superior e Investigación Científica” (MAR99-1060CO3-01, 02 and 03). ${ }^{210} \mathrm{~Pb}$ analysis of sediment trap samples was conducted in the laboratories at the School of Oceanography (University of Washington) by courtesy of Dr. C.A. Nittrouer. We thank to the officers and crew of R/V Garcia del Cid, and the UTM technicians, for their help during the deployment operations. Thanks also to all the IMEDEA and ICM personnel involved in the CANYONS project and surveys. Two anonymous reviewers helped to improve the manuscript. The comments of Dr. Jorge Guillen from ICM-CSIC were also very valuable to improve the text.

\section{References}

Alvarez, A., Tintoré, J. and Sabatés, A., 1996. Flow modification and shelf-slope exchange induced by a submarine canyon off the northeast Spanish Coast. J. Geophys. Res., 101 (C5):12043-12055.

Ardhuin, F., Pinot, J.M. and Tintoré, J., 1999. Numerical study of the circulation in a steep canyon off the Catalan coast (western Mediterranean). J. Geophys. Res., 104 (C5):11115-11135.

Bacon, M.P., Belastock, R.A. and Bothner, M.H., 1994. 210Pb Balance and implications for particle transport on the continental shelf, U.S: Middle Atlantic Bight. Deep-Sea Res., Part II, 41:511-535.

Biscaye, P.E., Flagg, C.N. and Falkowsky, P.G., 1994. The Shelf Edge Exchange Processes experiment: SEEP-II: an introduction to hypotheses, results and conclusions. Deep-Sea Res., Part II, 41:231-252.

Biscaye, P.E. and Anderson, R.F., 1994. Fluxes of particulate matter on the slope of the southern Middle Atlantic Bight: SEEP-II. Deep-Sea Res., Part II, 41:459-509.

Boyer, D.L., Zhang, X., and Pérenne, N., 2000. Laboratory observations of rotating, stratified flow in the vicinity of a submarine canyon. Dyn. Oceans. Atm., 31: 47-72.

Carbonne, J., 1991. Développement de techniques de prélèvement et d'analyse de la matière particulaire en océanologie. Diplôme universitaire de recherche, Univ. Perpignan. Perpignan, France, unpublished.

Cartes, J.E., 1998. Dynamics of the bathyal Benthic Boundary Layer in the northwestern Mediterranean: depth and temporal variations in macrofaunal-megafaunal communities and their possible connections within deep-sea trophic webs. Prog. Oceanogr., 41 (1):111-139.

Castellón, A., Font, J. and Garcia, E., 1990. The Liguro-Provençal-Catalan Current (NW Mediterranean) observed by Doppler profiling in the Balearic Sea. Sci. Mar., 54:266-276. 
Cros, L., 1995. Calcareous nannoplankton in surficial sediments of the Catalano-Balearic Sea (Northeastern Mediterranean). In: Flores, J.A. and Sierro, F.J. (Eds.), 5Th INA Conference in Salamanca Proceedings, pp. 47-59.

Chester, R., 1990. Marine Geochemistry. Unwin Hyman, London.

Durrieu de Madron, X., 1994. Hydrography and nepheloid structures in the Grand-Rhône canyon. Cont. Shelf. Res., 14:457-477.

Emelyanov, E.M. and Shimkus, K.M., 1986. Geochemistry and Sedimentology of the Mediterranean Sea. D. Reidel Publishing Company, Holland.

Etcheber, H., Heussner, S., Weber, O., Dinet, A., Durrieu de Madron, X., Monaco, A., Buscail, R. and Miquel, J.C., 1996. Organic carbon fluxes and sediment biogeochemistry on the French Mediterranean and Atlantic margins. In: Ittekkot, V., Schäfer, P., Honjo, S. and Depetris, P.J. (Eds.), Particle Flux in the ocean, SCOPE Report 57. John Wiley \& Sons, Chichester, pp. 223-241.

Fabres, J., Calafat, A., Sanchez-Vidal, A., Canals, M. and Heussner, S., 2002. Composition and spatiotemporal variability of particle fluxes in the Western Alboran Gyre, Mediterranean Sea. J. Mar. Syst., 3334:431-456.

Font, J., Salat, J. and Tintoré, J., 1988. Permanent features of the circulation in the Catalan Sea. Oceanol. Acta, 9:51-57.

Gardner, W.D., 1980. Field assessment of sediment traps. J. Mar. Res., 38:41-52.

Gardner, W.D., 1985. The effect of tilt on sediment trap efficiency. Deep-Sea Res., Part A, 32 (3):349361.

Gardner, W.D., 1989. Baltimore Canyon as a modern conduit of sediment to the deep sea. Deep-Sea Res., Part A, 36 (3):323-358.

Gili, J.M., Pages, F., Bouillon, J., Palanques, A., Puig, P., Heussner, S., Calafat, A., Canals, M. and Monaco, A., 2000. A multidisciplinary approach to the understanding of hydromedusan populations inhabiting Mediterranean submarine canyons. Deep-Sea Res., Part I, 47:1513-1533.

Gordon, D.C., 1970. Some studies on the distribution and composition of particulate organic carbon in the North Atlantic Ocean. Deep-Sea Res., 17:233-243.

Gracia, V., Jiménez, J.A. and Julià, A., 2003. La tormenta de Noviembre de 2001. Características e impactos a lo largo del litoral Catalán. VII Jornadas Españolas de Ingeniería de Costas y Puertos. Almeria, Spain, pp. 354-355.

de Haas, H., van Weering, T.C.E. and de Stigter, H., 2002. Organic carbon in shelf seas: sinks or sources, processes and products. Cont. Shelf. Res., 22:691-717.

Heussner S., Ratti C. and Carbonne J., 1990. The PPS 3 time-series sediment trap and the trap sample processing techniques used during the ECOMARGE experiment. Cont. Shelf. Res., 10:943-958.

Heussner, S., Calafat, A. and Palanques, A., 1996. Quantitative and qualitative features of particle fluxes in the North-Balearic Basin. In: Canals, M., Casamor, J.L., Cacho, I., Calafat, A., Monaco, A. (Eds.), EUROMARGE-NB Final Report, MAST II Programme, EU, vol. II, 41- 66, Chapter 3.

Heussner, S. Durrieu de Madron, X., Radakovitch, O., Beaufort, L., Biscaye, P.E., Carbonne, J., Delsaut, N., Etcheber, H. and Monaco, A., 1999. Spatial and temporal patterns of downward particle fluxes on the continental slope of the Bay of Biscay (northeastern Atlantic). Deep-Sea Res., Part II, 46:2101-2146.

Hickey, B, Baker, E. T., and Kachel, M., 1986. Suspended particle movement in and around Quinault submarine canyon. Mar. Geol., 71:35-83. 
Honda, M.C., Kusakabe, M., Nakabayashi, S., Manganini, S.J. and Honjo, S., 1997. Change in pCO2 through Biological Activity in the Marginal Seas of the Western North Pacific: The Efficiency of the Biological Pump Estimated by a Sediment Trap Experiment. J. Oceanogr., 53:645-662.

Honjo, S., Manganini, S.J. and Cole, J.J., 1982. Sedimentation rates of biogenic matter in the deep ocean. Deep-Sea Res., Part A, 29 (5):609-625.

Honjo, S., 1996. Fluxes of particles to the interior of the open oceans. In: Ittekkot, V., Schäfer, P., Honjo, S. and Depetris, P.J. (Eds.), Particle Flux in the ocean, SCOPE Report 57. John Wiley \& Sons, Chichester, pp. 91-113.

Hung, J.-J. , Lin, C.-S., Chung, Y.-C., Hung, G.-W and Liu, W.-S., 2003. Lateral fluxes of biogenic particles through the Min-Hua canyon in the southern East China Sea slope. Cont. Shelf. Res., 23:935955.

Ibarra Damiá, V. and Medina, J.R., 2003. Los temporales de Noviembre de 2001 en la costa Mediterránea: Obras de reparación en los puertos de Benicarló y Denia. VII Jornadas Españolas de Ingeniería de Costas y Puertos. Almeria, Spain, pp. 364-366.

Katayama, H. and Watanabe, Y., 2003. The Huanghe and Changjiang contribution to seasonal variability in terrigenous particulate load to the Okinawa Trough. Deep-Sea Res., Part II, 50:475-485.

Klinck, J.M., 1996. Circulation near submarine canyons: A modelling study. J. Geophys. Res., 101 (C1):1211-1223.

Knauer, G.A. and Asper, V.L. (Eds.)., 1989. U.S. GOFS Planning Report Number 10: Sediment Trap Technology and Sampling. U.S. Joint Global Ocean Flux Study (JGOFS) Planning Office, Woods Hole, 94 pp.

Legeleux, F., Reyss, J.-L., Etcheber, H. and Khripounoff, A., 1996. Fluxes and balance of ${ }^{210} \mathrm{~Pb}$ in the tropical northeast Atlantic. Deep-Sea Res., Part I, 43 (8):1321-1341.

Liu, K.-K., Atkinson, L., Chen, C.T.A., Gao, S., Hall, J. MacDonald, R.W., Talaue McManus, L., and Quiñones, R., 2000. Exploring continental margin carbon fluxes on a global scale. Eos, Transactions, American Geophysical Union, 81 (52):641-644.

Margalef, R., 1997. Our Biosphere. Ecology Institute, Oldendorf/Luhe, Germany.

Masó, M., La Violette, P.E. and Tintoré, J., 1990. Coastal flow modification by submarine canyons along the NE Spanish Coast. Sci. Mar., 54 (4):343-348.

Masqué, P. 1999. Estudi del comportament del 210Pb i el 210Po en el mar catalanobalear i el seu ús com a radiotraçadors. Ph. D. Thesis. Univ. Barcelona, Barcelona, Spain, unpublished.

Masqué, P., Fabres, J., Canal, M., Sánchez-Cabeza, J.A., Sánchez-Vidal, A., Cacho, I., Calafat, A.M. and Bruach, J.M., 2003. Accumulation rates of major constituents of hemipelagic sediments in the deep Alboran Sea: a centennial perspective of sedimentary dynamics. Mar. Geol., 193:207-233.

Masuzawa, T., Li, T., Duan, Y., Yamamoto, M., Hibi, Y., Nakatsuka, T., Kitazato, H. and Kato, Y., 2003. Temporal variation in mass fluxes and the major components of sinking particles in Sagami Bay, off Japan. Prog. Oceanogr., 57:59-75.

Millot, C., 1999. Circulation in the Western Mediterranean Sea. J. Mar. Syst., 20:423-442.

Miquel, J.C., Fowler, S.W., La Rosa, J. and Buat-Menard, P., 1994. Dynamics of the downward flux of particles and carbon in the open northwestern Mediterranean Sea. Deep-Sea Res., Part I, 41:243-261.

Monaco, A., Courp, T., Heussner, S., Carbonne, J., Fowler, S.W. and Deniaux, B., 1990a. Seasonality and composition of particulate fluxes during ECOMARGE-I, western Gulf of Lions. Cont. Shelf. Res., 10:959-987. 
Monaco, A., Biscaye, P., Soyer, J., Pocklington, R. and Heussner, S., 1990b. Particle fluxes and ecosystem response on a continental margin: the 1985-1988 Mediterranean ECOMARGE experiment. Cont. Shelf. Res., 10:809-839.

Monaco, A., Durrieu de Madron, X., Radakovitch, O., Heussner, S., and Carbonne, J., 1999. Origin and variability of downward biogeochemical fluxes on the Rhône continental margin (NW Mediterranean). Deep-Sea Res., Part I, 46:1483-1511.

Moore, W.S. and Dymondt, J., 1988. Correlation of ${ }^{210} \mathrm{~Pb}$ removal with organic carbon fluxes in the Pacific Ocean. Nature, 331:339-341.

Mortlock, R.A and Froelich, P.N., 1989. A simple method for the rapid determination of biogenic opal in pelagic marine sediments. Deep-Sea Research, Part A, 36 (9):1415-1426.

Nittrouer, C.A., Sternberg, R.W, Carpenter, R. and Bennett, J.T., 1979. The use of Pb-210 geochronology as a sedimentological tool: Application to the Washington continental shelf. Mar. Geol., 31:297-316.

Palanques, A., García-Ladona, E., Gomis, D., Martín, J., Marcos, M., Pascual, A., Emelianov, M., Puig, P., Guillén, J., Gili, J.M., Tintoré, J., Jordi, A., Basterretxea, G., Font, J., Segura, M., Blasco, D., Montserrat, S., Ruiz, S. and Pages, F. 2005a., A multidisciplinary program to study the dynamics and the ecology of a Northwestern Mediterranean submarine canyon: The Palamós Canyon. Prog. Oceanogr. (in press).

Palanques, A., Martín, J., Puig, P., Guillén, J., Companys, J.B. and Sardà, F., 2005b. Evidences of sediment gravity flows induced by trawling in the Palamós (Fonera) submarine canyon (northwestern Mediterranean). Deep-Sea Res. (submitted).

Petrenko, A. A., 2003. Variability of circulation features in the Gulf of Lion NW Mediterranean Sea. Importance of inertial currents. Oceanol. Acta, 26:323-338.

Puig, P. and Palanques, A., 1998. Temporal Variability and composition of settling particle fluxes on the Barcelona continental margin (Northwestern Mediterranean). J. Mar. Res., 56:639-654.

Puig, P., Palanques, A., Guillén, J. and García-Ladona, E., 2000. Deep slope currents and suspended particle fluxes in and around the Foix submarine canyon (NW Mediterranean). Deep-Sea Res., Part I, 47:343-366.

Puig, P., Ogston, A.S., Mullenbach, B.L. Nittrouer, C.A. and Sternberg, R.W., 2003. Shelf-to-canyon sediment-transport processes on the Eel continental margin (northern California). Mar. Geol., 193:129149.

Radakovitch, O. and Heussner, S., 1999. Fluxes and budget of ${ }^{210} \mathrm{~Pb}$ on the continental margin of the Bay of Biscay (northeastern Atlantic). Deep-Sea Res., Part II, 46:2175-2203.

Radakovitch, O., Sánchez-Cabeza, J.A., Abassi, A., Masqué, P. and Heussner, S., 2003. Meso and smallscale variations of $210 \mathrm{~Pb}$ fluxes on the Northwestern Mediterranean continental margins. Cont. Shelf Res., 23:693-715.

Ravaioli, M., Alvisi, F. and Menegazzo Vitturi, L., 2003. Dolomite as a tracer for sediment transport and deposition on the northwestern Adriatic continental shelf (Adriatic Sea, Italy). Cont. Shelf Res., 23:13591377.

Serra, J., 1981. Els canyons submarins del marge continental Català. Treb. Inst. Cat. Hist. Nat., 9:53-57.

Thomas, S. and Ridd, P.V., 2004. Review of methods to measure short time scale sediment accumulation. Mar. Geol., 207:95-114.

Walsh, J.J. , Rowe, G.T., Iverson, R.L. and McRoy, C.P., 1981. Biological export of shelf carbon: a neglected sink of the global CO2 cycle. Nature, 291:196-201. 
Wollast, R. and Chou, L., 2001. Ocean Margin Exchange in the Northern Gulf of Biscay: OMEX I. An introduction. Deep-Sea Res., Part II, 48:2971-2978.

Xu, J.P., Noble, M., Eittreim, S.L., Rosenfeld, L.K., Schwing, F.B. and Pilskaln, C.H., 2002. Distribution and transport of suspended particulate matter in Monterey Canyon, California. Mar. Geol., 181:215-234. 


\section{Table and Figure Captions}

Table 1. Locations and depths of sediment traps deployed in the Palamós submarine canyon and nearby open slope. Current meter and pressure transducer data relevant for trap efficiency assessment are also shown.

Table 2. Time weighted mean fluxes $\left(m g \mathrm{~m}^{-2} \mathrm{~d}^{-1}\right)$ and flux weighted mean concentrations (\% of dry weight) for each sediment trap. The Contribution (\%) of the Storm on Fluxes (C.S.F.) is also shown.

Table 3. Mean ${ }^{210} \mathrm{~Pb}$ concentrations (weighted by flux and time), time-weighted mean ${ }^{210} \mathrm{~Pb}$ fluxes, and total mass fluxes from sediment traps deployed in the Palamós submarine canyon.

Table 4. Correlation coefficients (R-squared) between ${ }^{210} \mathrm{~Pb}$ activity and major constituent contents (linear fit) and TMF (power function fit) from sediment traps M2, M3B, M3I and M5.

Table 5. Correlation coefficients (R-squared, linear fit) between ${ }^{210} \mathrm{~Pb}$ activity and major constituent contents of sediment trap samples (M2, M3B, M3I and M5), divided in five consecutive time periods. Correlation coefficients between ${ }^{210} \mathrm{~Pb}$ activity and Total Mass Flux (linear fit) also shown.

Figure 1. Top image, bathymetric map of the northwest Mediterranean margin. The area is incised by several submarine canyons, some of which, like Palamós canyon, cut the continental shelf at shallow depths. The mean path of the Northern Current is also outlined. Below, bathymetry of the Palamós Canyon and mooring positions. Each mooring sustained a near-bottom sediment trap. Mooring M3 had an additional sediment trap at intermediate depths.

Figure 2. Hydrological and oceanographic background during the experiment, collected in surrounding sites: A. Hydrological station at the Ter River; B, C. Oceanographic Buoy near Palamós. Gaps in the buoy time series are filled with values predicted in a nearby WANA point (model).

Figure 3. Bar graphs illustrate the time series of total mass and main constituents fluxes of particulate matter for each sediment trap during the study period. Note the different scaling of graphs.

The left-bottom line graph shows the time series of total mass flux for all the sediment traps, merged together with the same scale.

Figure 4. Lithogenic contents (dots) and fluxes (bars) of sediment trap samples during the study period.

Figure 5. Carbonate contents (dots) and fluxes (bars) of sediment trap samples during the study period. 
Figure 6. Organic carbon contents (dots) and fluxes (bars) of sediment trap samples during the study period.

Figure 7. Biogenic silica contents (dots) and fluxes (bars) of sediment trap samples during the study period.

Figure 8. ${ }^{210} \mathrm{~Pb}$ total activity (dots) and fluxes (bars) of sediment trap samples during the study period.

Figure 9. ${ }^{210} \mathrm{~Pb}$ activities plotted against versus total mass fluxes, for all the samples analysed. (Circles: Trap M2 ; Triangles: Trap M3B ; Squares: Trap M3I ; Crosses: Trap M5). A power function is used to fit all the data.

Figure 10. Major particulate constituent contents versus total mass fluxes from sediment trap samples.

Figure 11. Test of relationships between particulate main contents for all sediment trap samples.

Figure 12. Difference between total mass fluxes of M3B and M2 traps. Positive values during summer represent an excess of fluxes in M3B (1200 m depth) in comparison to M2 (470 m depth) and has been related to sediment gravity flows triggered by human activities. The marked negative balance of the penultimate bar is the imprint of the first stages of the November storm (last bar). 
Table_1

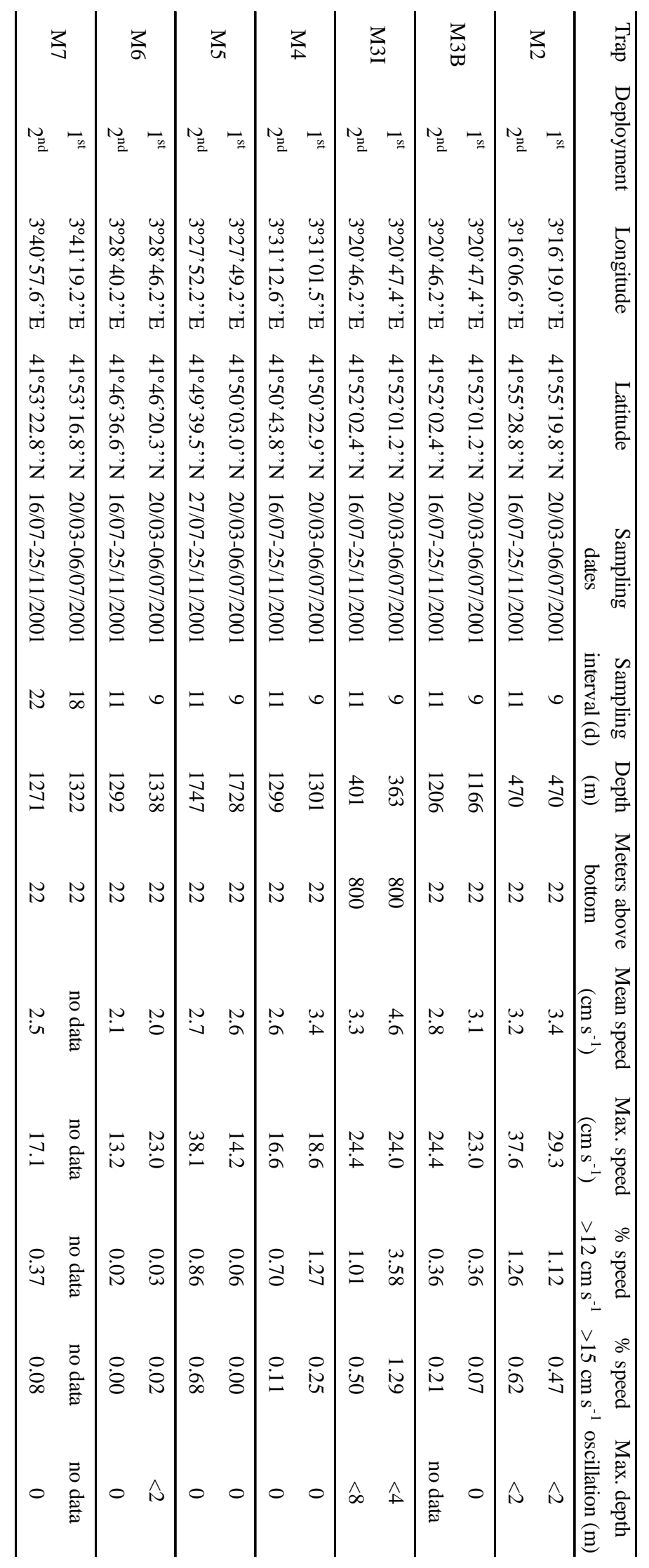


Table_2

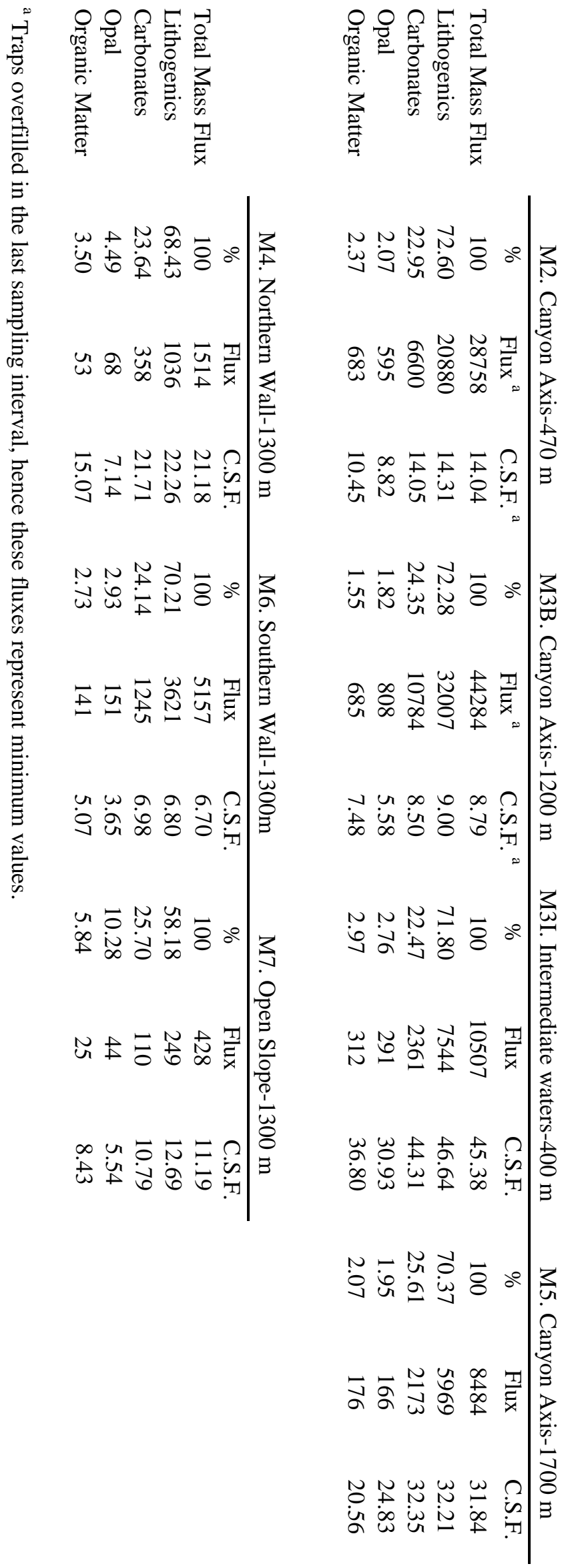


Table_3

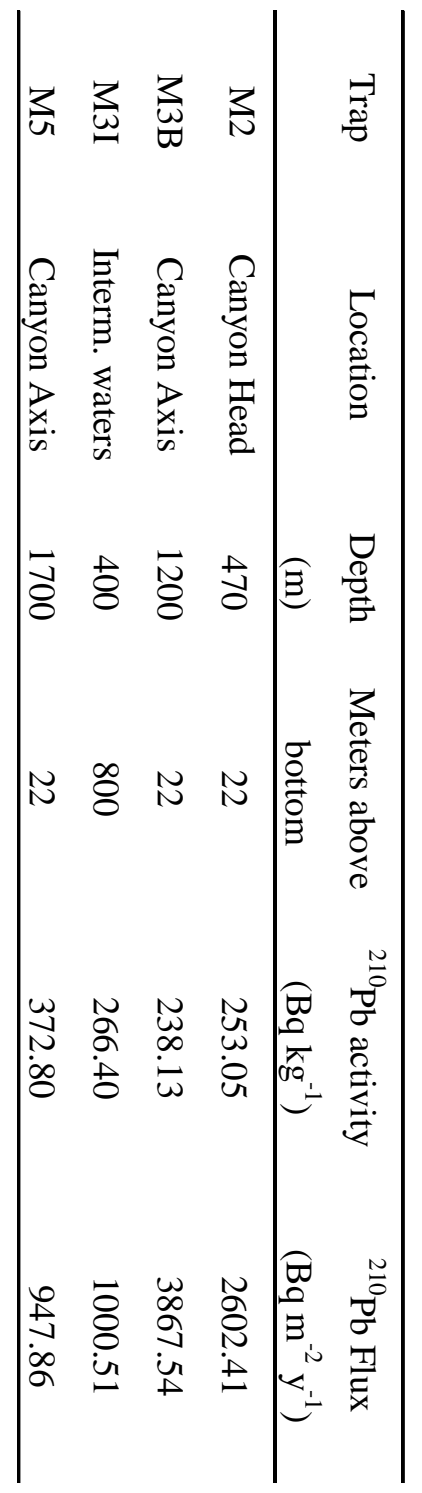


Table_4

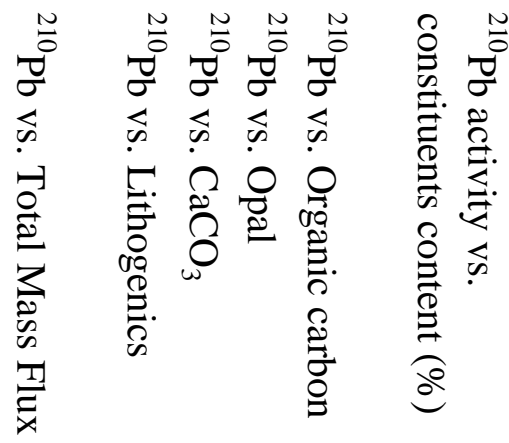

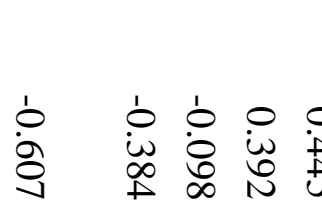

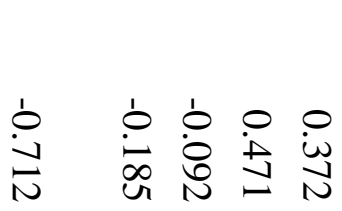

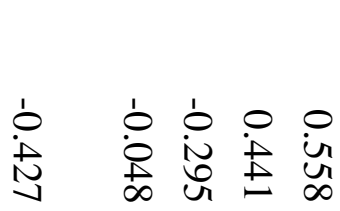

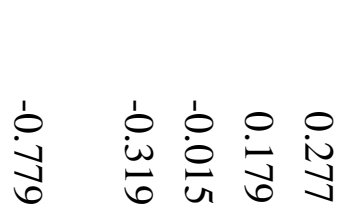

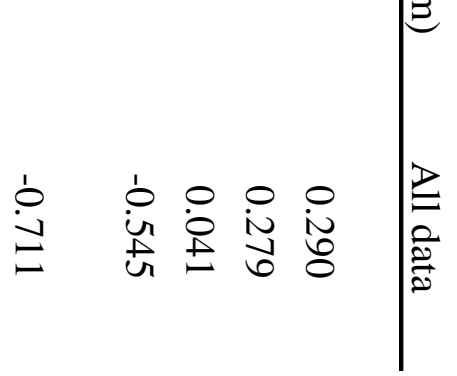


Table_5

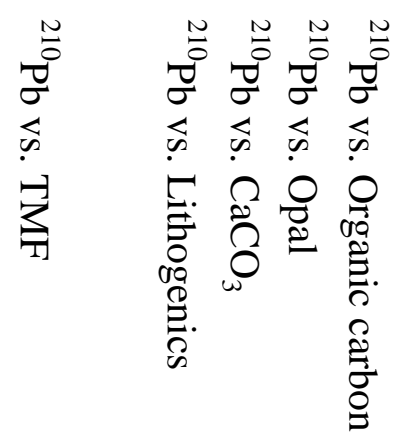

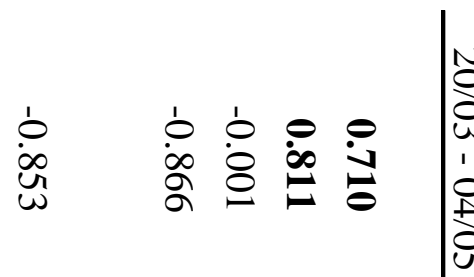

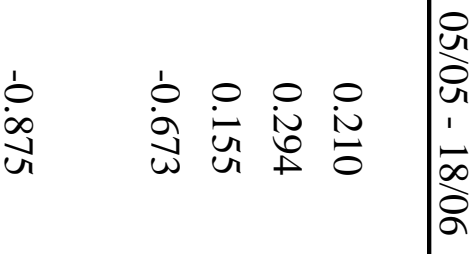

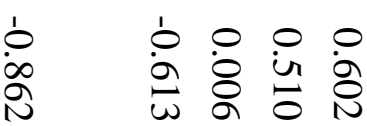

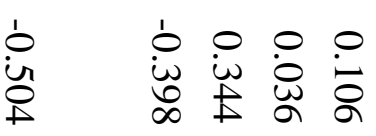

$\stackrel{8}{\dddot{2}}$

+

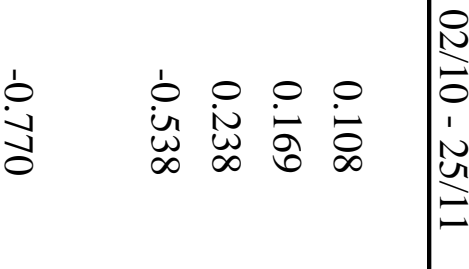


Figure_1
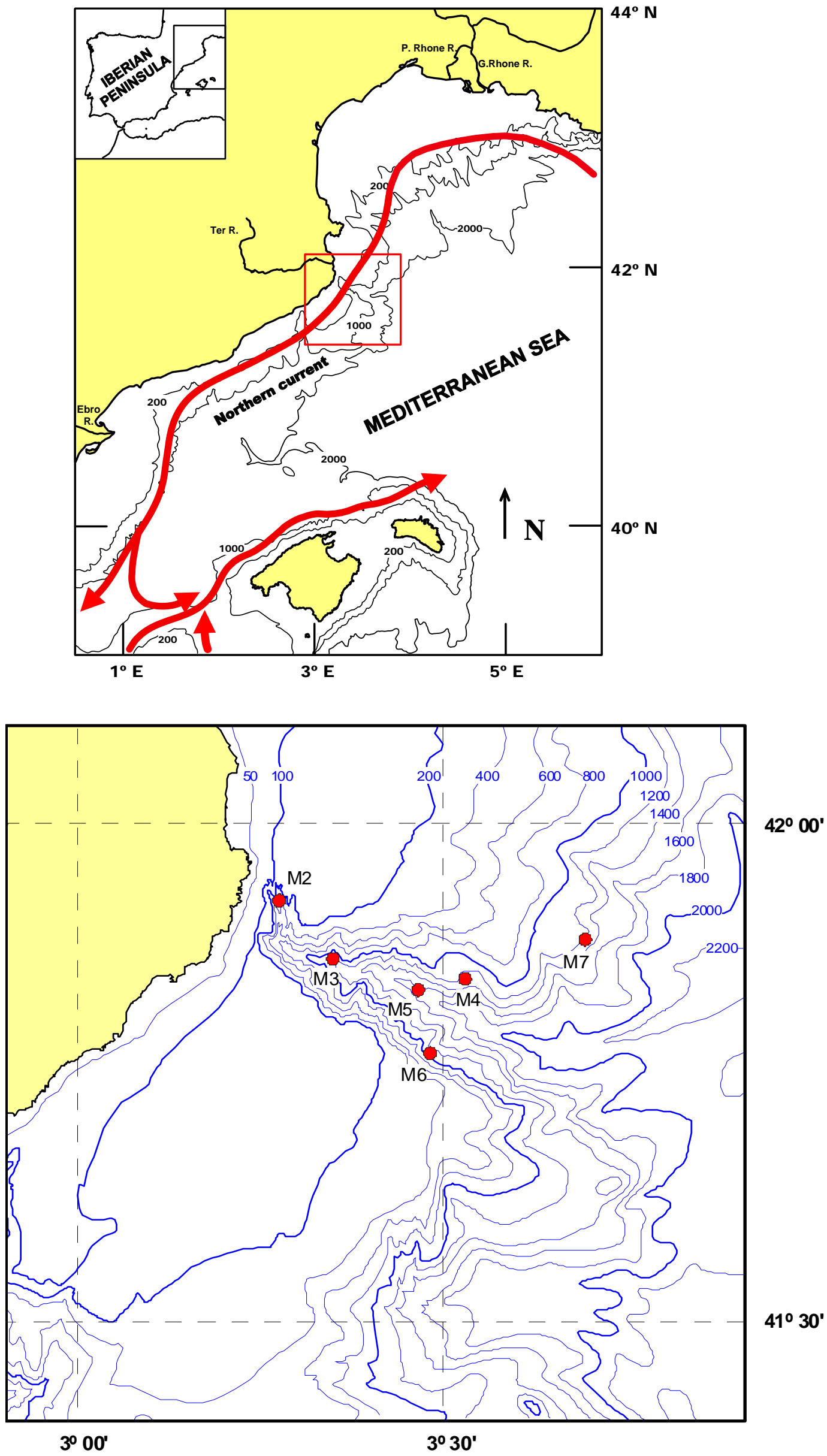
Figure_2
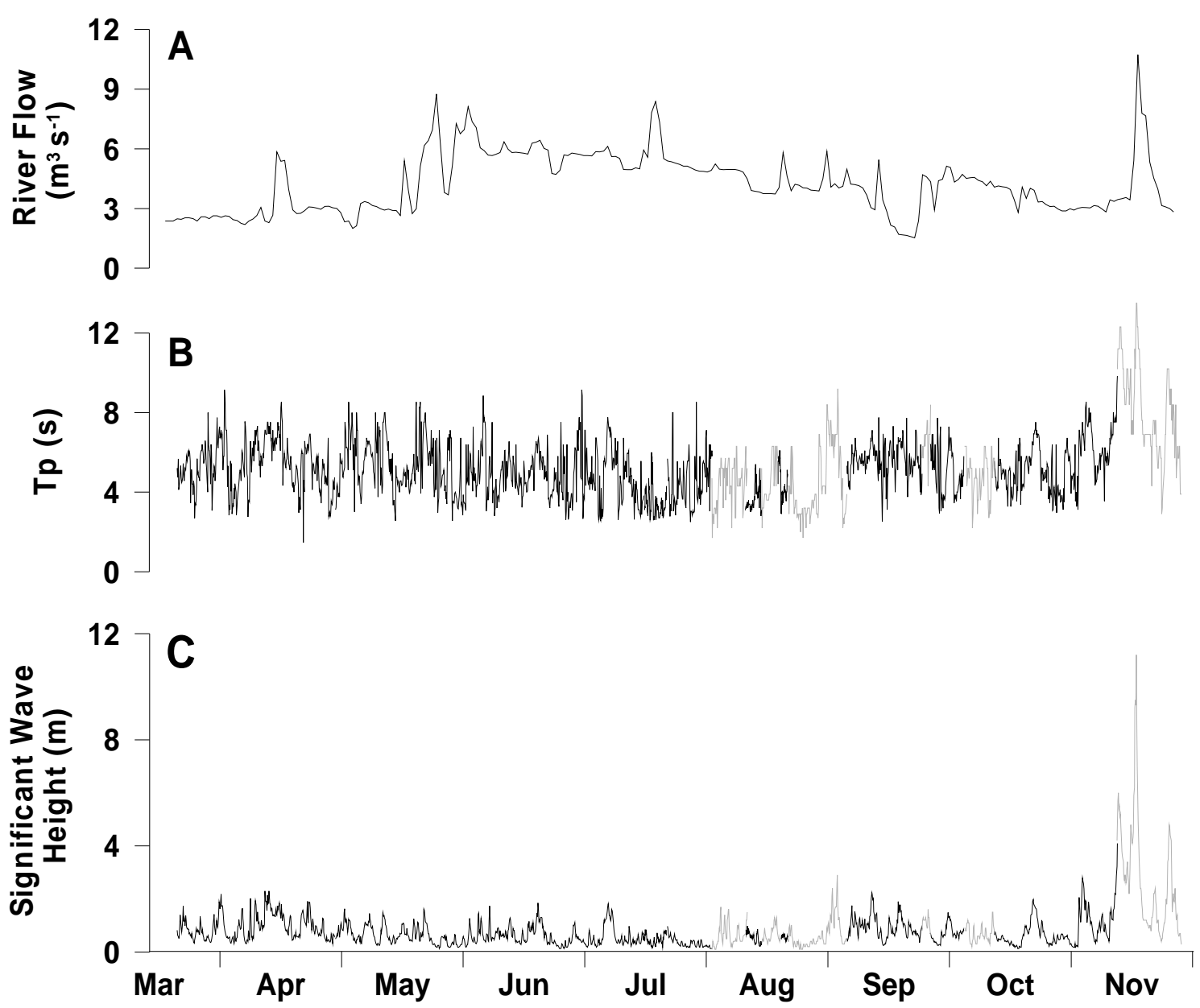
Figure_3
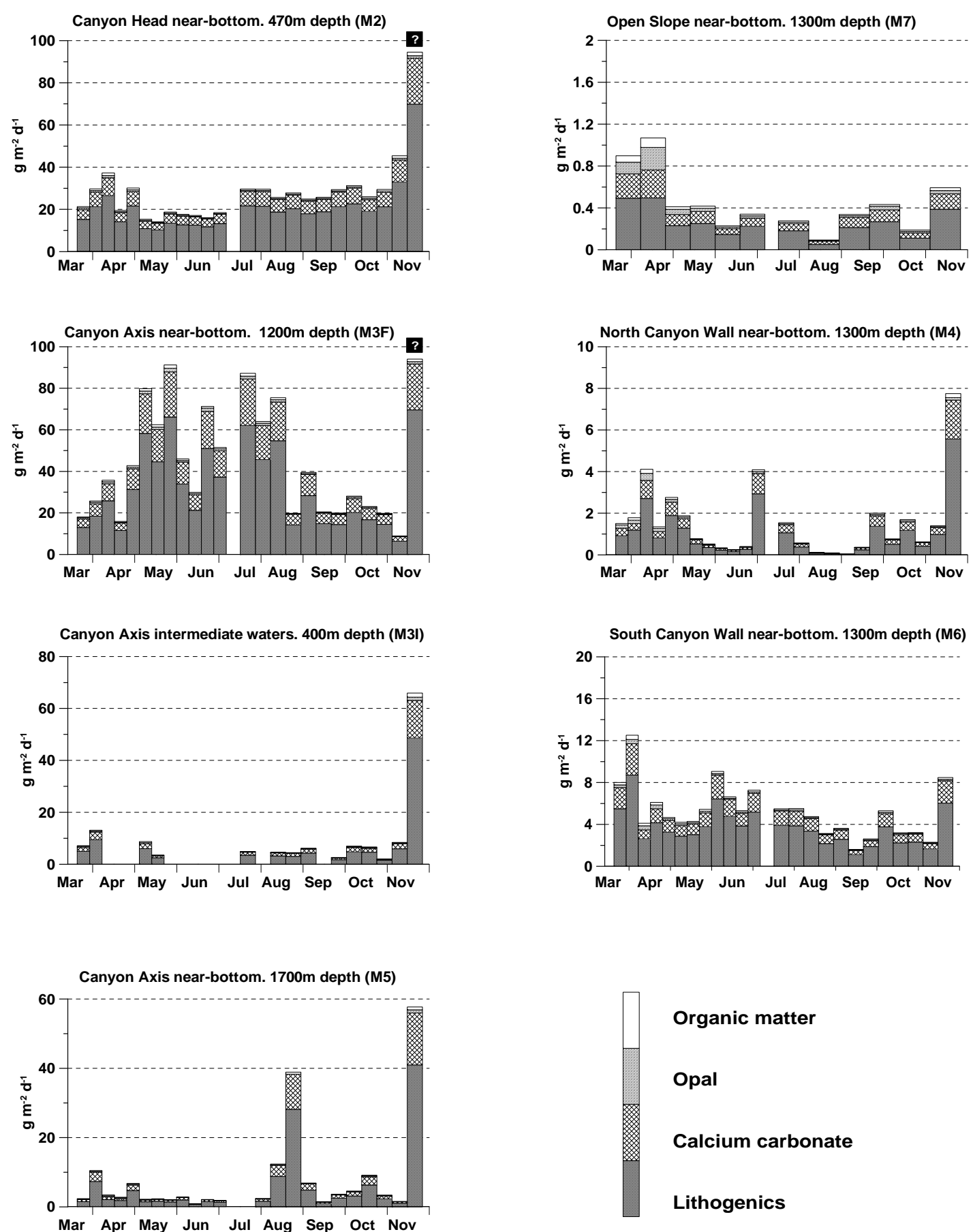

\section{Organic matter}

Opal

Calcium carbonate

Lithogenics

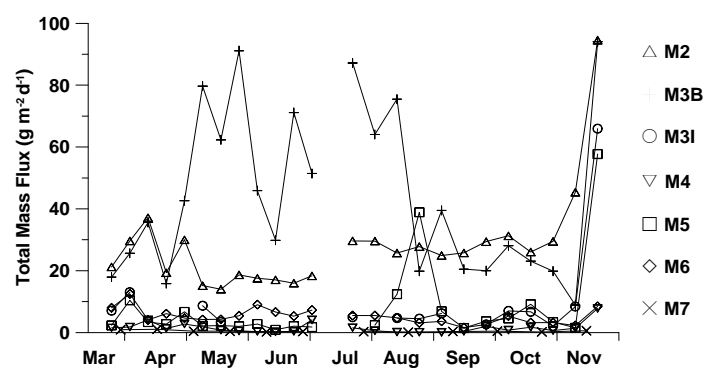


Figure_4
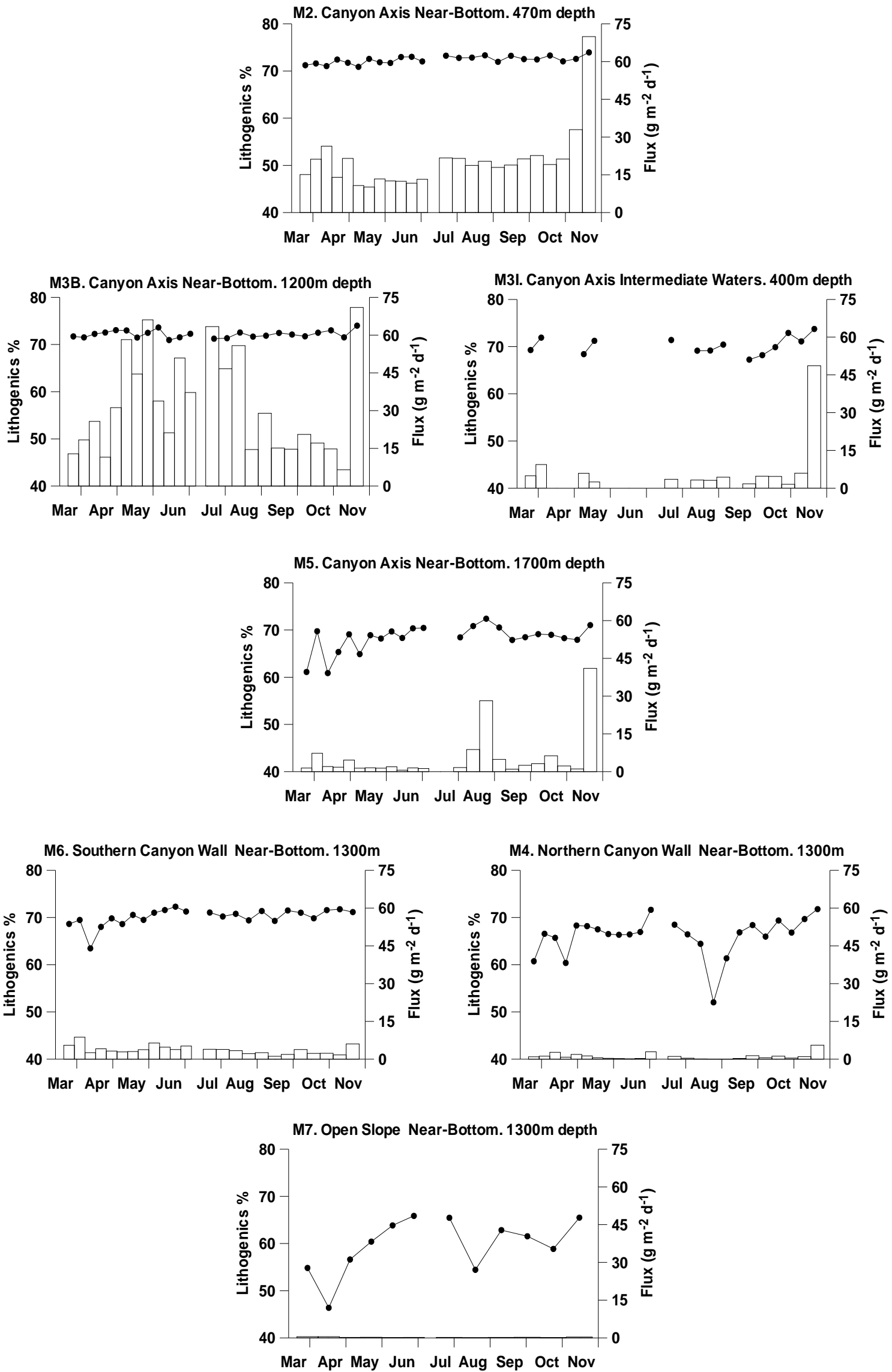
Figure_5
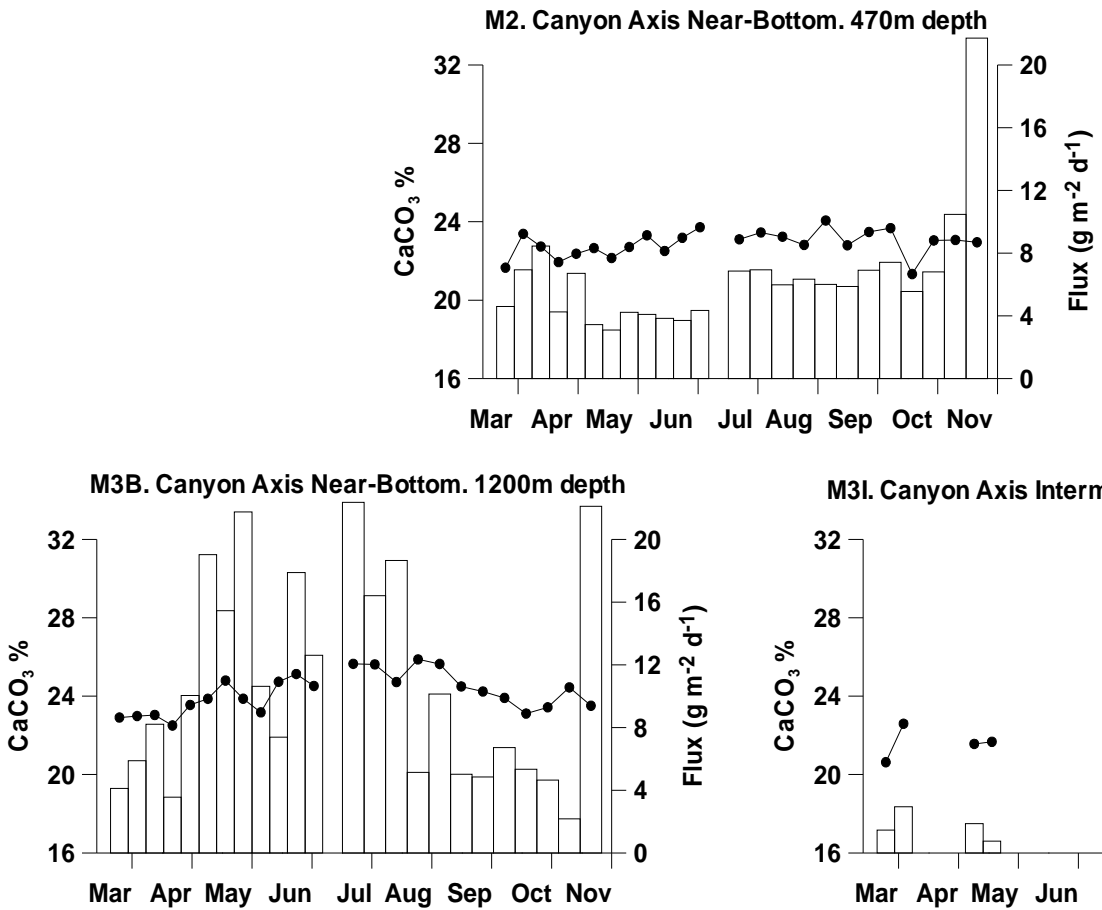

M3I. Canyon Axis Intermediate Waters. 400m depth
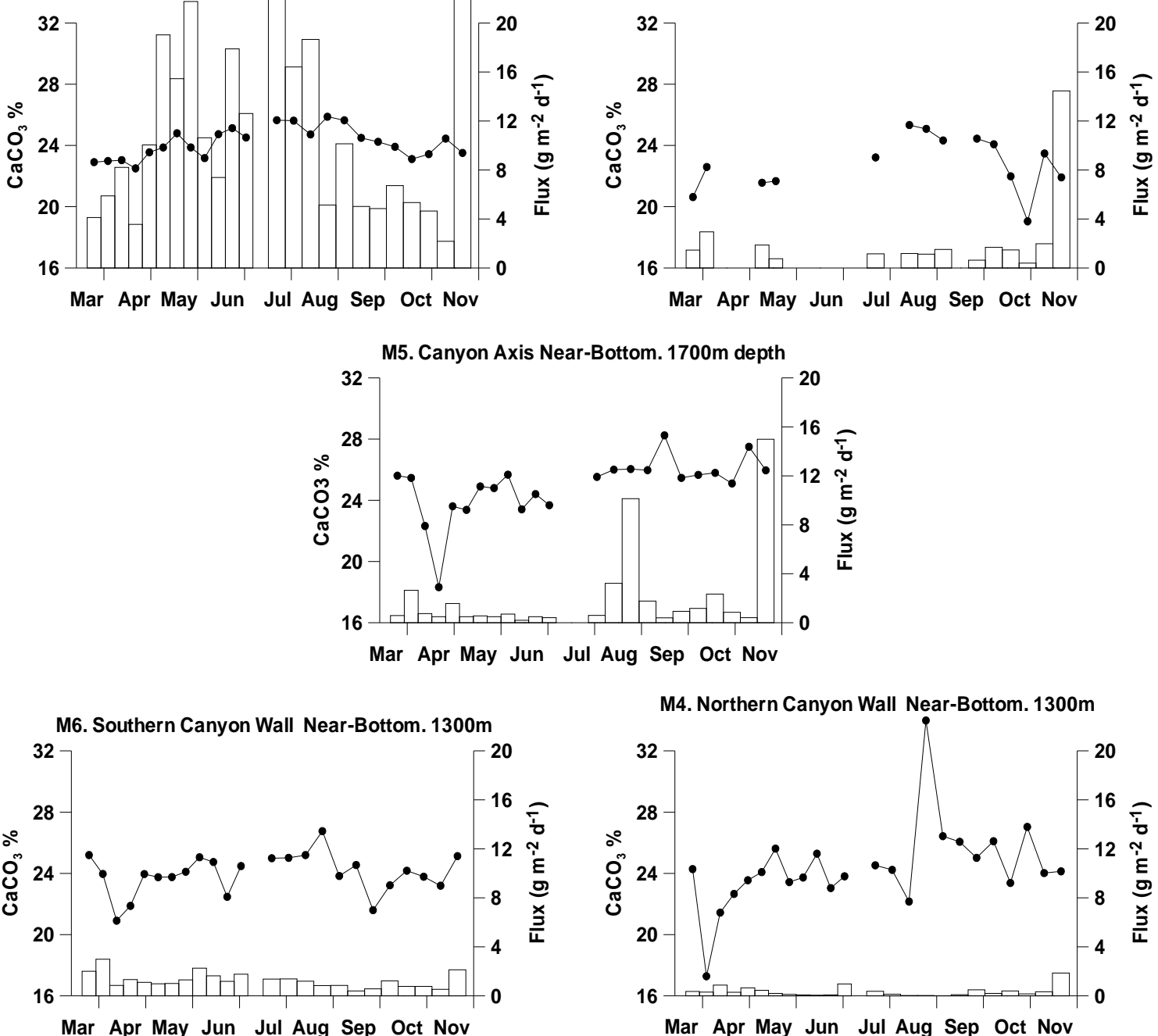

M4. Northern Canyon Wall Near-Bottom. 1300m

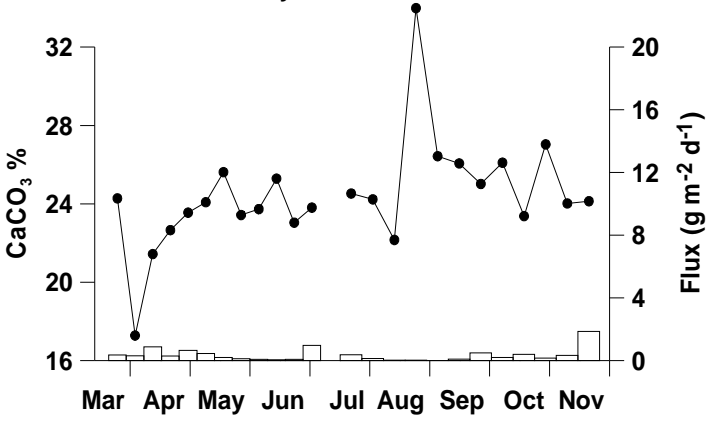

M7. Open Slope Near-Bottom. 1300m depth

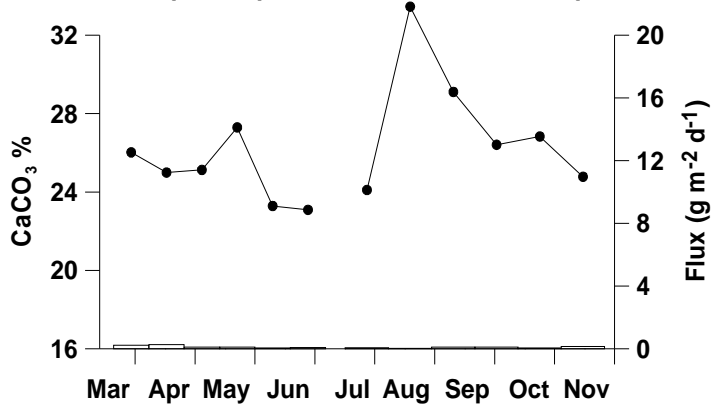


Figure_6
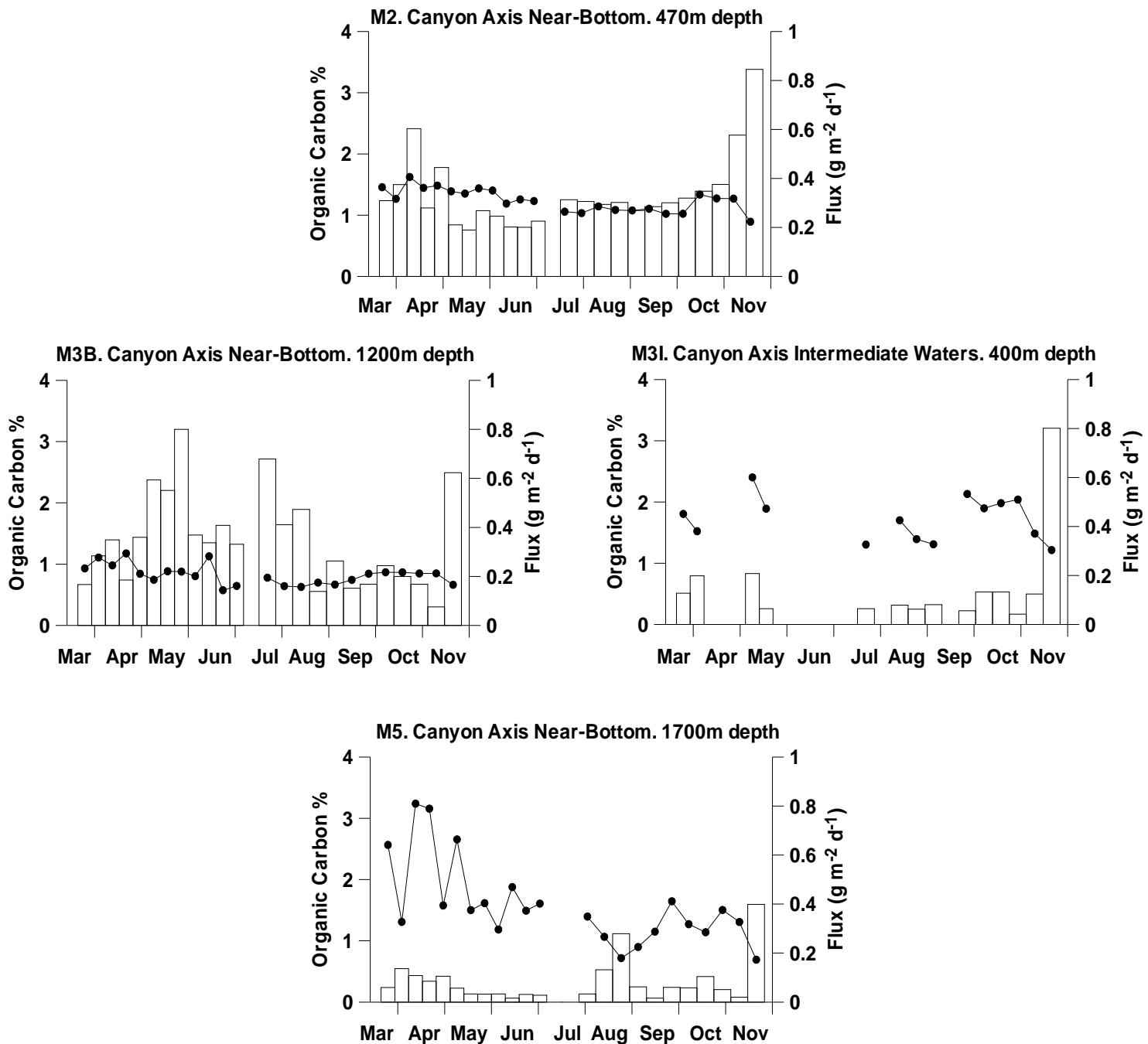

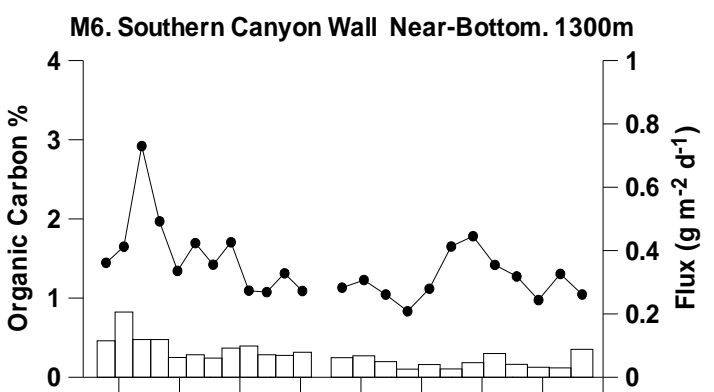

Mar Apr May Jun Jul Aug Sep Oct Nov

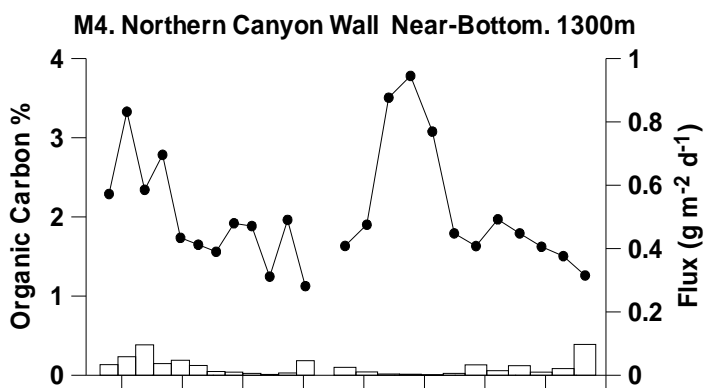

Mar Apr May Jun Jul Aug Sep Oct Nov

M7. Open Slope Near-Bottom. 1300m depth

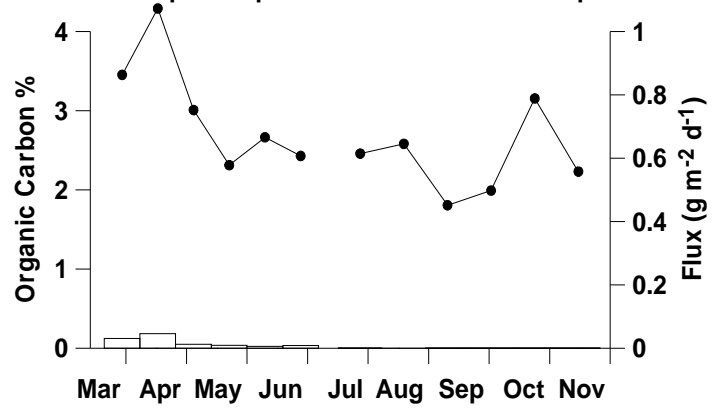


Figure_7
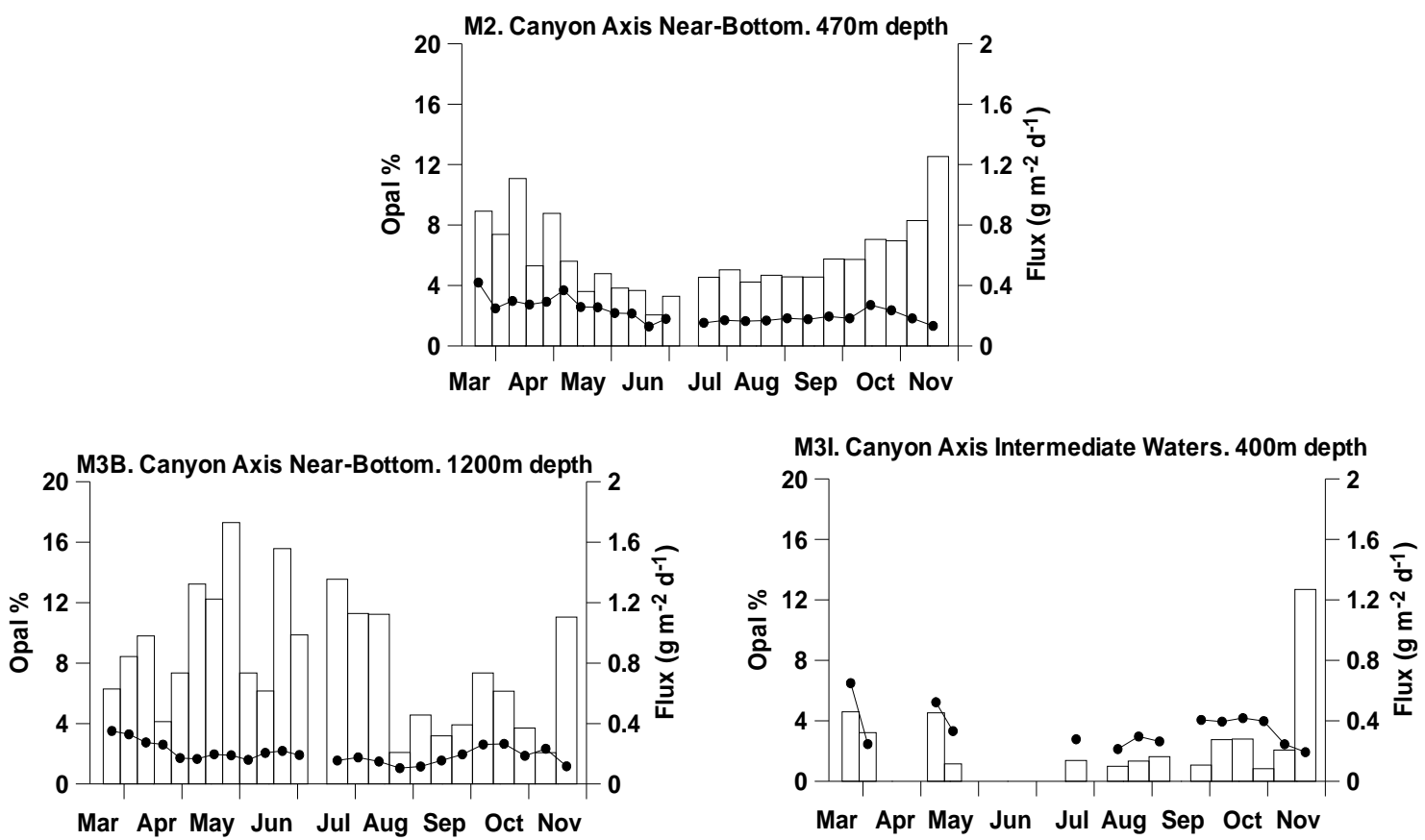

M5. Canyon Axis Near-Bottom. 1700m depth

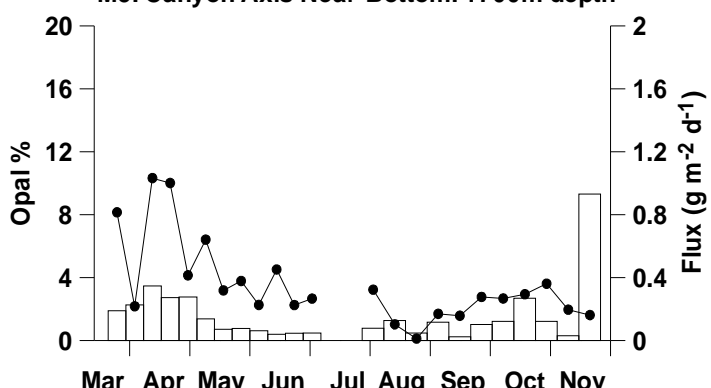

M6. Southern Canyon Wall Near-Bottom. $1300 \mathrm{~m}$

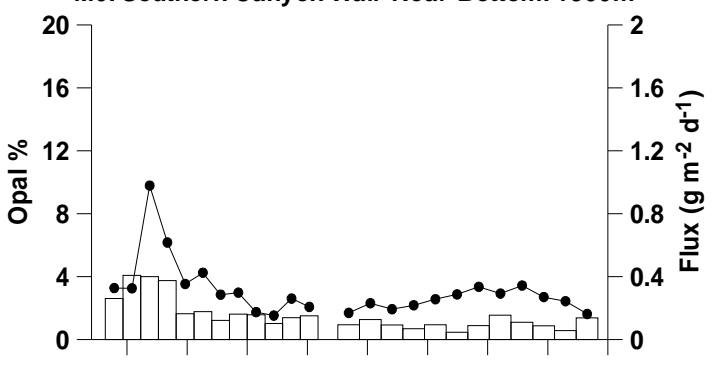

Mar Apr May Jun Jul Aug Sep Oct Nov

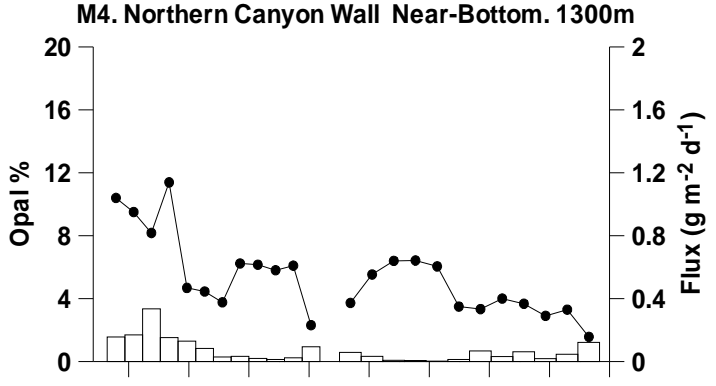

Mar Apr May Jun Jul Aug Sep Oct Nov

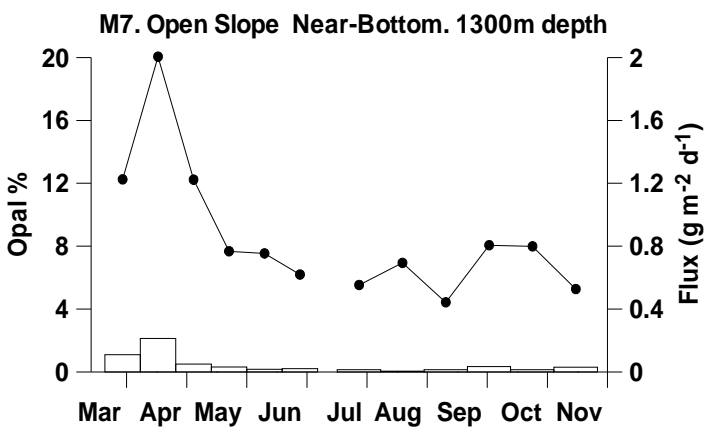


Figure_8
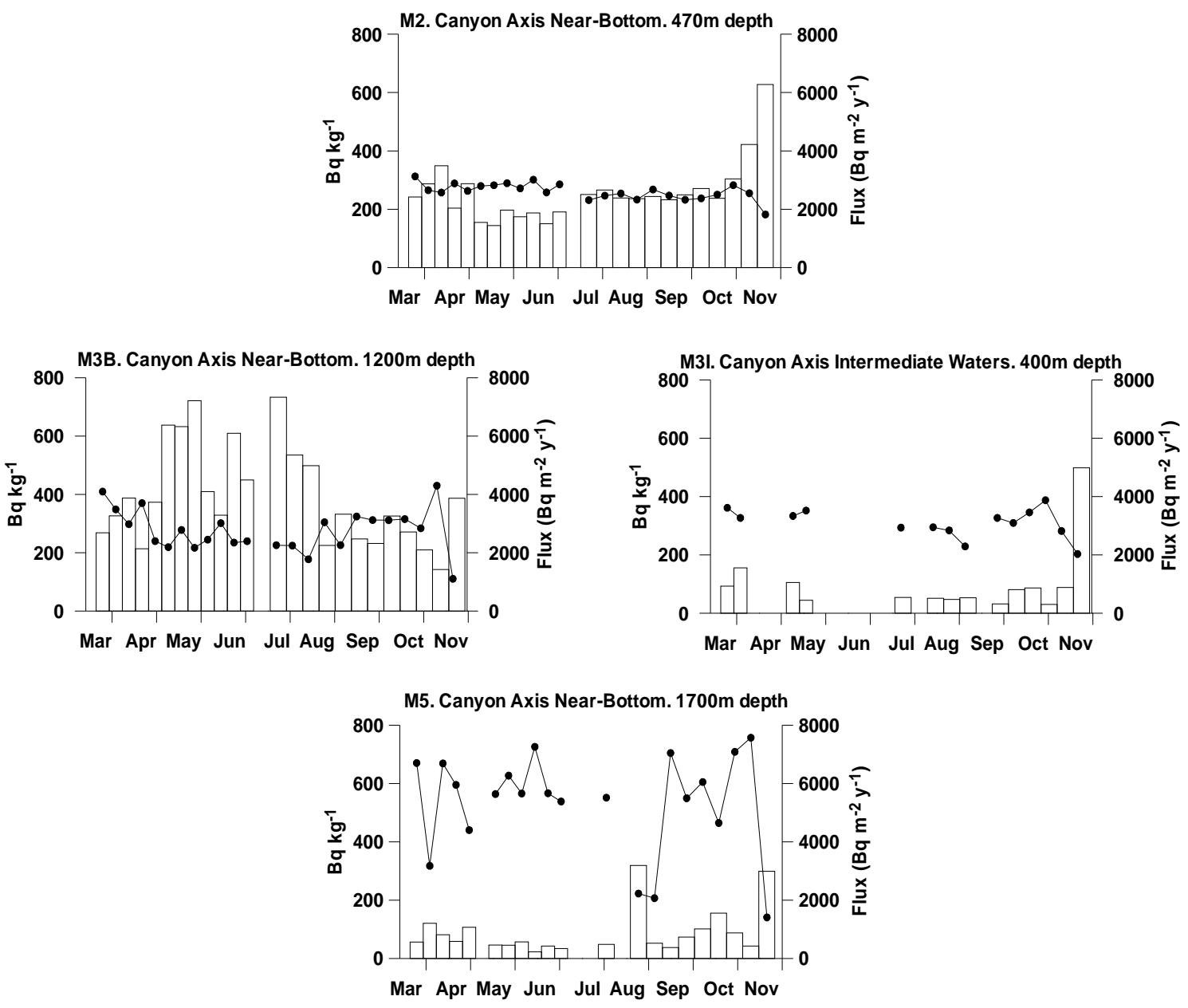
Figure_9

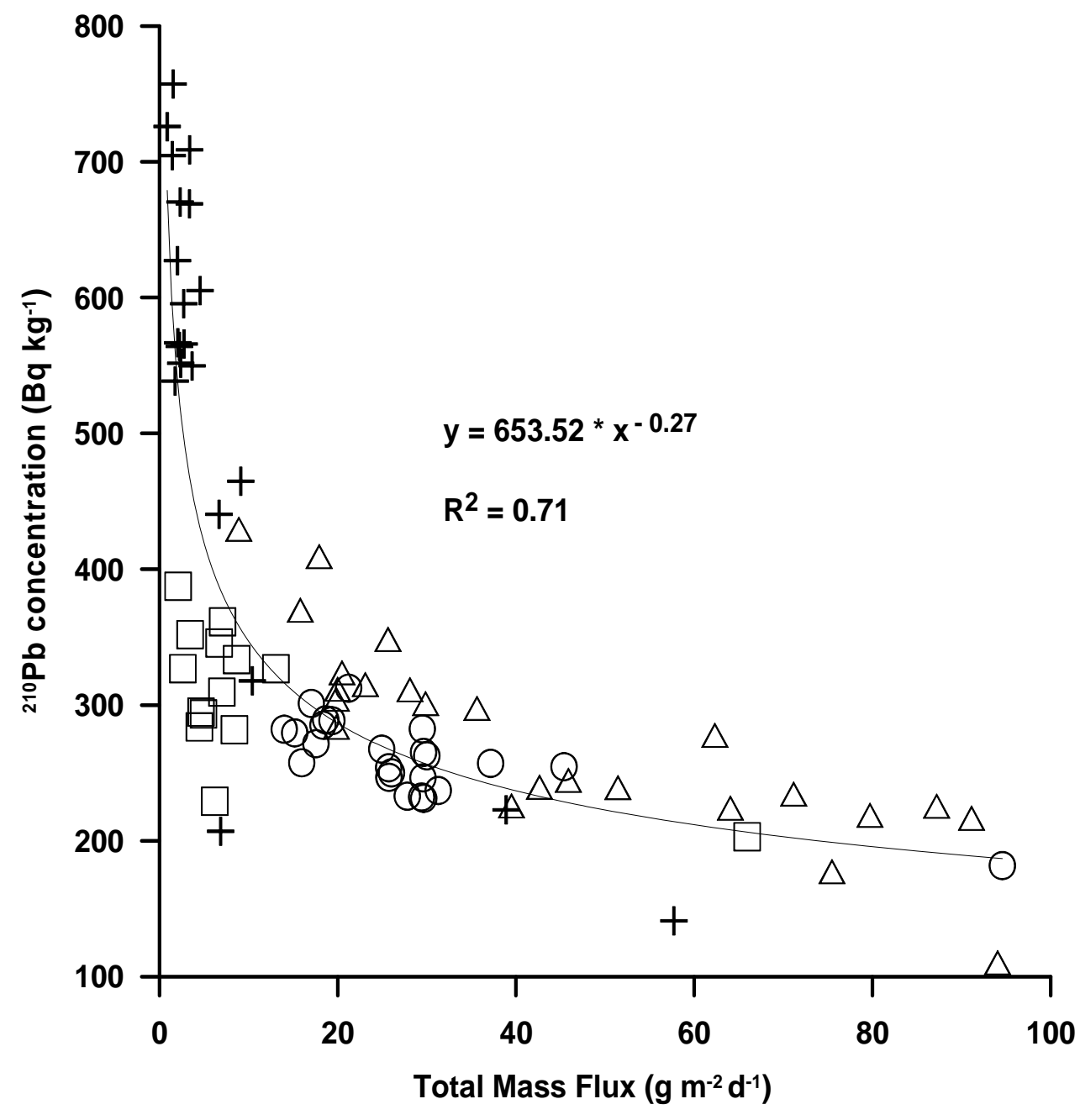


Figure_10
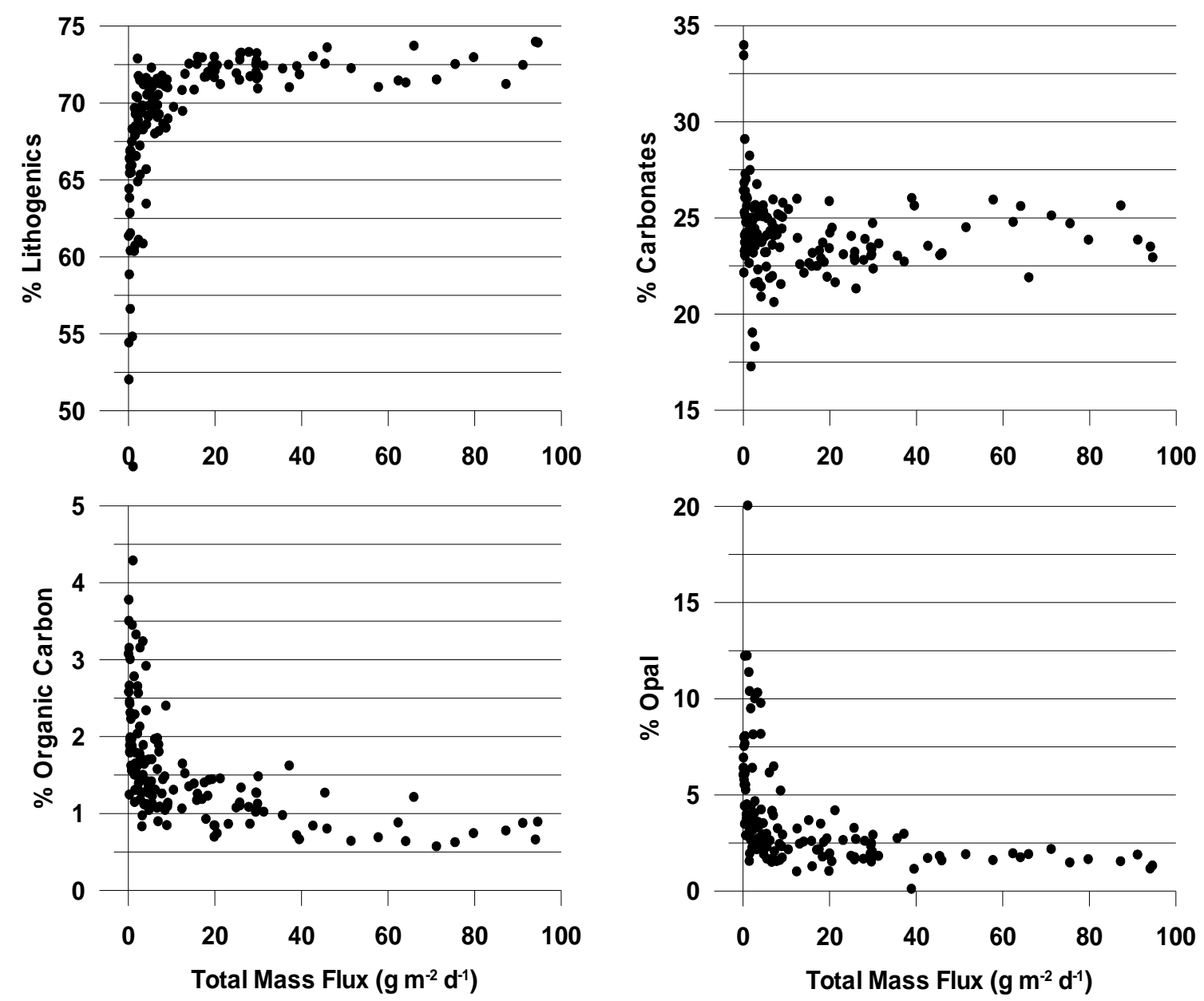
Figure_11
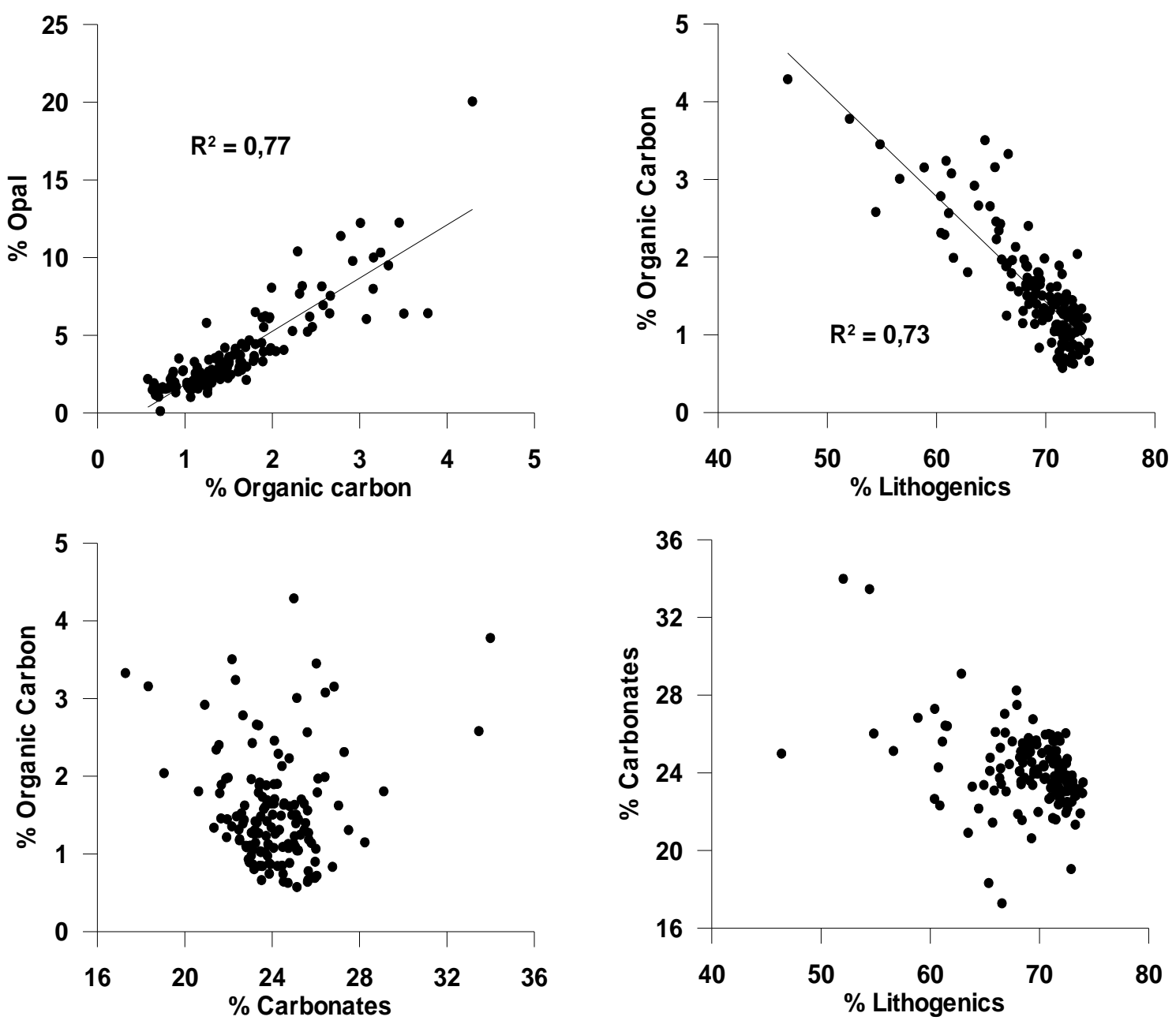
Figure_12

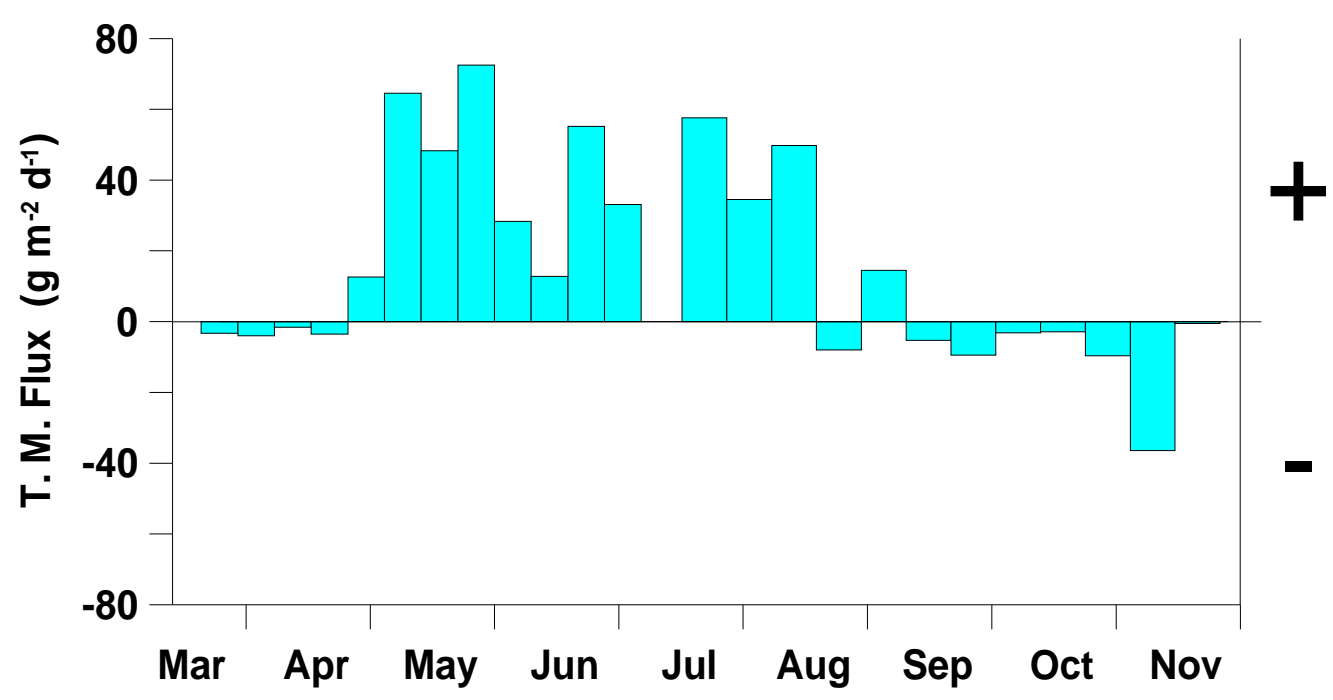

